\title{
Peningkatan Keuntungan Usahatani di Kabupaten Sidoarjo Melalui Optimasi Pemberian Air dengan Program Linier
}

\author{
Increasing Farming Profits in Sidoarjo Regency Through Optimization of Water Supply \\ with Linear Programs
}

${ }^{1}$ Fahrul \& ${ }^{凶 2}$ Munari Kustanto

${ }^{1}$ Dinas Pekerjaan Umum Bina Marga dan Sumber Daya Air Kabupaten Sidoarjo, Indonesia ${ }^{2}$ Badan Perencanaan Pembangunan Daerah Kabupaten Sidoarjo, Indonesia

DOI: $10.32781 /$ cakrawala.v15i2.383

\begin{tabular}{l} 
ARTICLE INFO \\
Keuntungan Optimal, \\
Optimasi, \\
Program Linier, \\
Usahatani. \\
\hline \\
Article History: \\
Received : 11 Okt 2021 \\
Accepted : 9 Nov 2021 \\
Publish : 24 Des 2021
\end{tabular}

Publish : 24 Des 2021

\begin{abstract}
Abstrak:
Penelitian ini bertujuan menganalisa keuntungan optimal usahatani di Kabupaten Sidoarjo melalui pengaturan pola tanam dan pemberian air yang tepat sesuai dengan ketersediaan air. Menggunakan pendekatan deskriptif kuantitatif, penelitian ini dilakukan di Kabupaten Sidoarjo yang masuk dalam daerah irigasi Delta Brantas. Analisis terhadap data dilakukan menggunakan program linier dengan perangkat lunak Solver pada Microsoft Excel. Optimasi dilakukan terhadap empat skenario dengan empat alternatif masa tanam (MT) yaitu November I, November II, Desember I dan Desember II. Hasil penelitian menunjukkan bahwa skenario III memberikan keuntungan optimal paling tinggi. Melaluipemaksimalan tanaman padi dan palawija diperoleh keuntungan optimal sebesar Rp. 600.433.180.505,-. Luas tanam MT I adalah padi seluas 21.984 ha, MT II adalah padi seluas 8.386 ha dan palawija (jagung/kedelai) seluas 9.896 ha, serta MT III adalah palawija (jagung/ kedelai) seluas $8.110 \mathrm{ha}$.

\section{Abstract:}

This study aims to analyze the optimal profit of farming in Sidoarjo Regency through setting the right cropping pattern and water supply in accordance with the availability of water. Using a quantitative descriptive approach, this research was conducted in Sidoarjo Regency which is included in the Brantas Delta irrigation area. Analysis of the data was carried out using a linear program with Solver software in Microsoft Excel. Optimization was carried out on four scenarios with four alternative planting periods (MT), namely November I, November II, December I and December II. The results showed that scenario III provides the highest optimal profit. By maximizing rice and secondary crops, the optimal profit is $R p .600,433,180,505,-$. The planted area of MT I is paddy on 21,984 ha, MT II is rice on 8,386 ha and palawija (corn/soybean) on 9,896 ha, and MT III is palawija (maize/soybean) covering an area of $8,110 \mathrm{ha}$.
\end{abstract}

\footnotetext{
Corresponding author:

Address : Jln Sultan Agung No. 13, Magersari, Kabupaten Sidoarjo61212 Jawa Timur

Email : munarikustanto@gmail.com
}

Hal. 188-212

p-ISSN 1978-0354 | e-ISSN 2622-013X 


\section{PENDAHULUAN}

Salah satu isu penting dalam pembangunan di Indonesia adalah terkait dengan ketahanan pangan. Semakin meningkatnya populasi penduduk tentu berdampak pada penyediaan kebutuhan pangan yang juga terus meningkat. Pada sisi lain, peningkatan populasi juga memberikan dorongan bagi terjadinya alih fungsi lahan pertanian.

Kabupaten Sidoarjo termasuk salah satu wilayah lumbung padi di Provinsi Jawa Timur yang turut memasok kebutuhan pangan nasional.Kabupaten Sidoarjo disebut sebagai Kota Delta karena terletak di dataran rendah dan diapit oleh dua sungai besar yaitu Kali Mas dan Kali Porong. Kondisi alam tersebut menjadikan Kabupaten Sidoarjo daerah yang subur untuk pertanian, khususnya padi dan palawija.

Sebagai salah satu daerah penyangga ibu kota provinsi, Kabupaten Sidoarjo juga mengalami pertumbuhan penduduk yang cukup tinggi baik secara alami maupun migrasi. Kondisi tersebut tentu berpengaruh terhadap lahan pertanian yang ada di Kabupaten Sidoarjo. Kebutuhan akan tempat tinggal dan industri merupakan salah satu penyebab alih fungsi lahan yang terjadi di Kabupaten Sidoarjo. Sedangkan pada sisi lain kebutuhan pangan penduduk otomatis juga semakin tinggi.

Dalam upaya memenuhi meningkatnya kebutuhan pangan, maka perlu dilakukan usaha mengoptimalkan lahan pertanian yang ada. Hal ini perlu dilakukan guna memperoleh keuntungan yang maksimal dari sektor pertanian. Salah satu komponen penting dalam pembangunan bidang pertanian sekaligus mewujudkan ketahanan pangan adalah irigasi.

Daerah irigasi Delta Brantas yang berada di Kabupaten Sidoarjo memperoleh pasokan air dari Bendung Lengkong di Kabupaten Mojokerto, tepatnya di Bangunan Bagi Kapajaran. Bendung
Lengkong atau juga dikenal dengan Rolak Songo ini merupakan pembagi dua jaringan besar yang ada di Delta Brantas. Kedua jaringan tersebut adalah Mangetan Kanal dan Porong Kanal (Idfi, 2010). Jaringan ini tidak hanya mensuplai kebutuhan air untuk pertanian, tetapi juga untuk industri dan air minum.

Pemenuhan kebutuhan air untuk irigasi dihadapkan pada permasalahan ketersediaan air yang terbatas. Dengan demikian diperlukan pengelolaan air irigasi yang baik guna mengatasi permasalahan tersebut. Pengelolaan air irigasi umumnya dilakukan dengan pengaturan pemberian air irigasi dan pola tanam yang tepat pada lahan irigasi. Harapannya kebutuhan air tanaman pada areal tersebut dapat terpenuhi sesuai dengan periode pertumbuhan tanaman.

Ketersediaan air dan kebutuhan air tanaman dapat mengalami fluktuasi dari waktu ke waktu. Kondisi ini mengakibatkan terjadinya kelebihan dan kekurangan air pada periode tertentu. Berdasarkan ketersediaan air dan kebutuhan air pada suatu daerah irigasi, dapat dilakukan optimasi pemberian air dengan pengaturan pola tanam. Hal ini guna melakukan pengelolaan air irigasi yang optimum. Optimasi dapat dilakukan dengan membuat alternatif terhadap perubahan rencana tata tanam pada daerah irigasi untuk mendapatkan luas tanam yang optimal. Dengan demikian dapat menghasilkan keuntungan hasil produksi pertanian yang maksimal.

Memperhatikan uraian tersebut, maka diperlukan adanya penanganan yang terpadu dan komprehensif pada pengelolaan pemberian air di daerah irigasi Delta Brantas. Optimasi pemberian air pada daerah irigasi tersebut perlu dilakuan agar mampu memenuhi kebutuhan air, baik untuk irigasi, domestik, maupun industri secara maksimal. Optimasi dalam penelitian ini adalah optimasi pemberian air dan pengaturan pola tanam pada daerah 
irigasi Delta Brantas Kabupaten Sidoarjo dengan program linier untuk meningkatkan pendapatan petani.

Studi mengenai upaya peningkatan keuntungan usahatani sudah banyak dilakukan dengan berbagai pendekatan. Peningkatan pendapatan petani dapat dilakukan melalui peningkatan produksi, pemanfaatan hasil sampingan, optimasi unsur usahatani, menjaga kestabilan harga (Tumiwa and Sondakh, 2018), memperluas pengalaman (Ningsih dkk., 2015). Upaya peningkatan pendapatan juga dilakukan melalui pengelolaan lahan yang terintegrasi dengan industri (Kanti Dwi Cahyani, Marimin and Sukardi, 2017)there was untrust issue between farmers and sugarcane industry on yield measurement that impacting onfarmers' performance and income. The objective of this study was to formulate gainsharing productivity, with the following steps: 1 serta pemilihan metode tanam (Suhesti, 2018). Berbeda dengan studi sebelumnya, kajian ini menguraikan upaya peningkatan keuntungan usahatani melalui optimasi pemberian air.

Berbagai studi terkait optimasi pemberian air juga telah banyak dilakukan, salah satunya dilakukan oleh Sukri dan Balany (2017) di daerah irigasi Wawotobi, SulawesiTenggara. Hasilstudimenunjukkan bahwa kebutuhan air maksimum pada saat musim tanam saat persiapan lahan berbeda. Studi yang dilakukanHidayat, Harlan dan Winskayati(2014) pada daerah irigasi Wanir di Kabupaten Bandung danSilvia(2017) pada daerah irigasi Siman di Kabupaten Jombang menemukan bahwa pengaturan pola tanam juga diperlukan untuk mengoptimasi penambahan debit. Optimasi pemberian air dan pengaturan pola tanam akan memberikan keuntungan optimal bagi petani menurut Sayekti (2010) dan Noerhayati dkk. (2017), ketika melakukan studi pada Dam Jatimlerek di Kabupaten Jombang dan daerah irigasi Molek di Kabupaten Malang.
Penggunaan program linier untuk optimasijuga telah banyak dilakukan. Program linier digunakan untuk studi optimasi pola tanam di beberapa daerah seperti Kabupaten Magetan, Kabupaten Banyuwangi, Kabupaten Karawang, hingga Kabupaten Tanggamus (Setyono and Mucharom, 2016; Risfiyanto dkk., 2017; Frahmana, 2018; Setiawan dan Anwar, 2017). Program linier juga digunakan untuk studi optimasi pemberian air di Kabupaten Trenggalek dan Kabupaten Sumbawa (Bestari, 2017; Hermanto dkk., 2020). Studi yang memfokuskan optimasi pemberian air pada daerah irigasi Delta Brantas di Kabupaten Sidoarjo belum banyak dilakukan. Penelitian ini berupayamengisi kekosongan yang masih ditinggalkan studi sebelumnya, dalam hal ini mengupas optimasi pemberian air pada daerah irigasi Delta Brantas di Kabupaten Sidoarjo. Berapa keuntungan optimal pada hasil pertanian dengan melakukan pengaturan pola tanam dan pemberian air yang tepat sesuai dengan ketersediaan air menjadi rumusan masalah yang hendak dijawab dalam penelitian ini.

\section{TINJAUAN PUSTAKA}

Usahatani merupakan ilmu tentang pengelolaan sumberdaya baik lahan, tenaga kerja, modal, manajemen (Saeri, 2018), teknologi, pupuk, benih dan pestisida (Hafidh, 2009) yang dimiliki petani secara efektif, efisien, dan kontinyu guna mendapatkan keuntungan maksimal. Usahatani pada suatu waktu dan tempat pada dasarnya sangat dipengaruhi oleh kemampuan sumberdaya yang ada, termasuk sumberdaya air. Besaran kebutuhan air irigasi dipengaruhi oleh pola tanam dan jadwal tanam pada suatu areal irigasi.

Kebutuhan air sendiri merujuk pada kebutuhan air tanaman (consumptive use) ditambah dengan kehilangan karena sistem pembagian. Dalam hal ini kehilangan pada 
saluran serta pada saat pemberian di petak tanaman(Rudson, Soetopo and Limantara, 2014). Kebutuhan air dihitung dengan rumus.

$\mathrm{NFR}=\mathrm{ETc}+\mathrm{P}-\mathrm{Re}+\mathrm{WLR}$ (untuk padi) $\mathrm{NFR}=\mathrm{ETc}-\mathrm{Re}$ (untuk palawija/tebu)

Dimana NFR adalah kebutuhan air bersih di sawah (mm/hari), ETc adalah Evapotranspirasi actual atau penggunaan konsumtif tenaman selama Pertumbuhan ( $\mathrm{mm} /$ hari), P adalah perkolasi ( $\mathrm{mm} /$ hari), Re adalah hujan efektif (mm/hari), WLR adalah penggantian lapisan air ( $\mathrm{mm} / \mathrm{hari}$ ).

Optimasi pemberian air merupakan salah satu upaya efisiensi penggunaan sumberdaya petani. Optimasi pemberian air dan pola tanam merupakan integrasi dari data iklim, sumber air, agronomi, dan sosial ekonomi. Menurut Jayadi (1993)prinsip model optimasi adalah memperhatikan aspek tujuan semaksimal mungkin dan melibatkan segala kendala yang membatasi upaya pemanfaatan sumber daya air. Beberapa teknik optimasi yang umumnya digunakan antara lain pembagian zona peruntukan melalui rulecurve, pola pengoperasian baku, program linier, program dinamik deterministik, dan program dinamik stokastik (Suharyanto, 2005). Penelitian ini menggunakan program linier untuk mengoptimalkan pemberian air pada daerah irigasi Delta Brantas di Kabupaten Sidoarjo.

Penyelesaian masalah optimasi melalui program linier diawali dengan menentukan variabel keputusan yang akan dicari nilai optimumnya. Variabel keputusan ini selanjutnya dibentuk fungsi tujuannya. Kendala-kendala yang dihadapi kemudian diidentifikasi dan dinyatakan secara fungsional berupa persamaan atau pertidaksamaan. Manakala pemodelan selesai dibuat, barulah dilakukan perhitungan untuk mencapai kondisi optimum.

\section{METODE PENELITIAN}

Penelitian ini menggunakan metode deskriptif kuantitatif untuk mengetahui kondisi optimum pemberian air pada daerah irigasi Delta Brantas di Kabupaten Sidoarjo. Daerah Irigasi Delta Brantas merupakan daerah irigasi teknis yang berada di Kabupaten Sidoarjo, Provinsi Jawa Timur. Luas areal Daerah Irigasi Delta Brantas \pm 21.984 ha yang tersebar pada 17 kecamatan, sebagaimana terlihat pada lingkaran merah pada gambar 1 .

Penelitian ini menggunakan data sekunder berupa data-data teknis dari instansi yang berwenang dalam kurun waktu tahun 2004-2015. Instansi tersebut antara lain Dinas PU Bina Marga Kabupaten Sidoarjo, BMKG Juanda, UPTD Lengkong, Dinas Pertanian Kabupaten Sidoarjo, PDAM Delta Tirta, dan Perum Jasa Tirta I. Alur berfikir dan kebutuhan data dalam penelitian dapat dilihat pada gambar 2 .

Analisis terhadap sensitivitas data dilakukan dengan menggunakan program linier dengan bantuan software Solver. Sebuah fasilitas pencari solusi yang dikembangkan dari metode simplek. Perhitungan dengan Solver harus memenuhi unsur target yang ingin dicapai, kendala yang ditemui, dan sel yang diubah-ubah isinya untuk ditentukan nilainya agar target dan kendala dipenuhi.

Pembahasan hasil penyelesaian program linier terbagi dua yaitu perubahan koefisien fungsi tujuan dan perubahan koefisien fungsi kendala. Selanjutnya diidentifikasi nilai ketersediaan air irigasi, kebutuhan air irigasi (termasuk air minum dan industri), kemampuan teknis dan finansial petani dan keuntungan setiap jenis tanaman untuk dapat dilakukan optimasi dengan menggunakan model matematika berikut. 


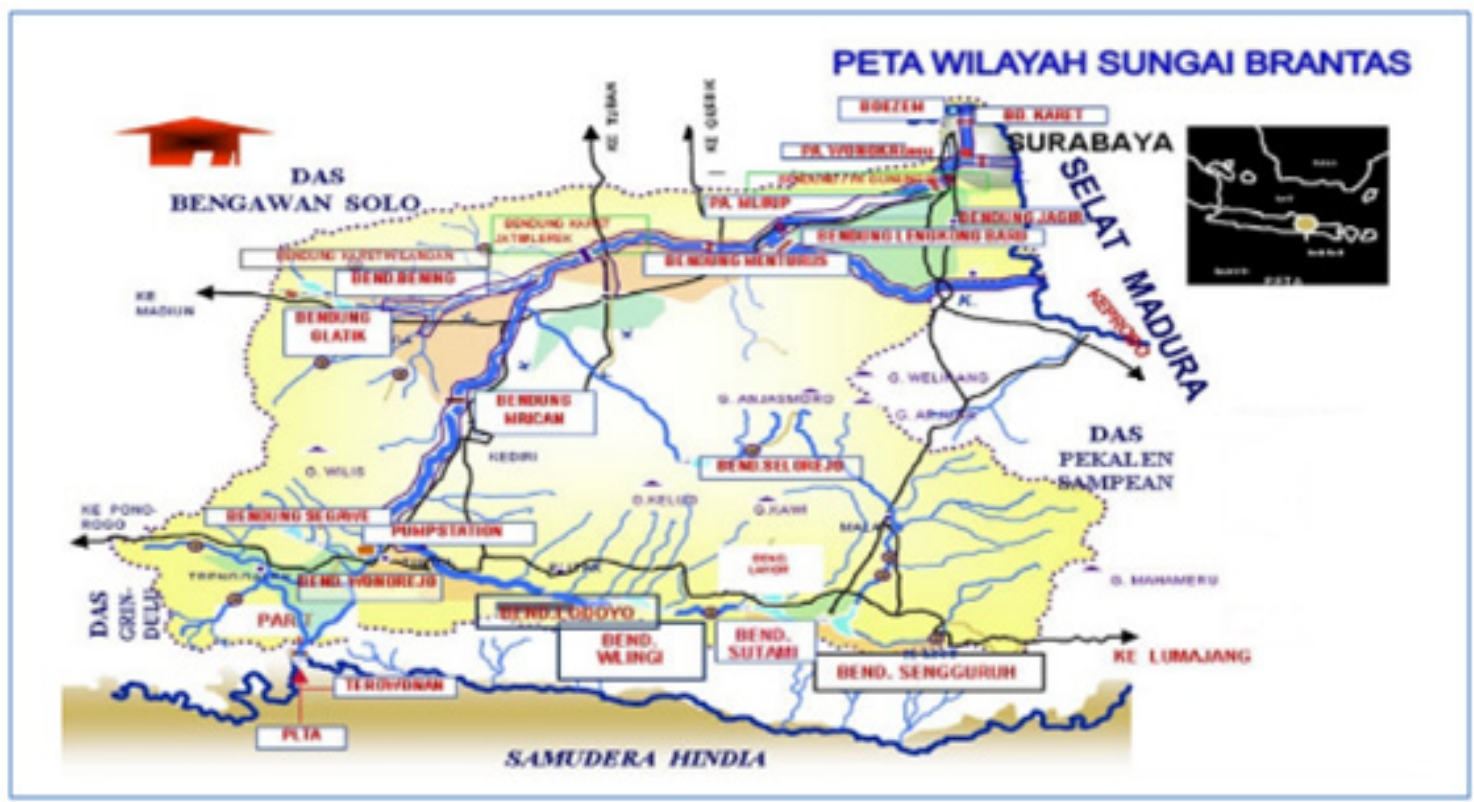

Sumber: BBWS, 2010

Gambar 1

\section{Lokasi Penelitian}

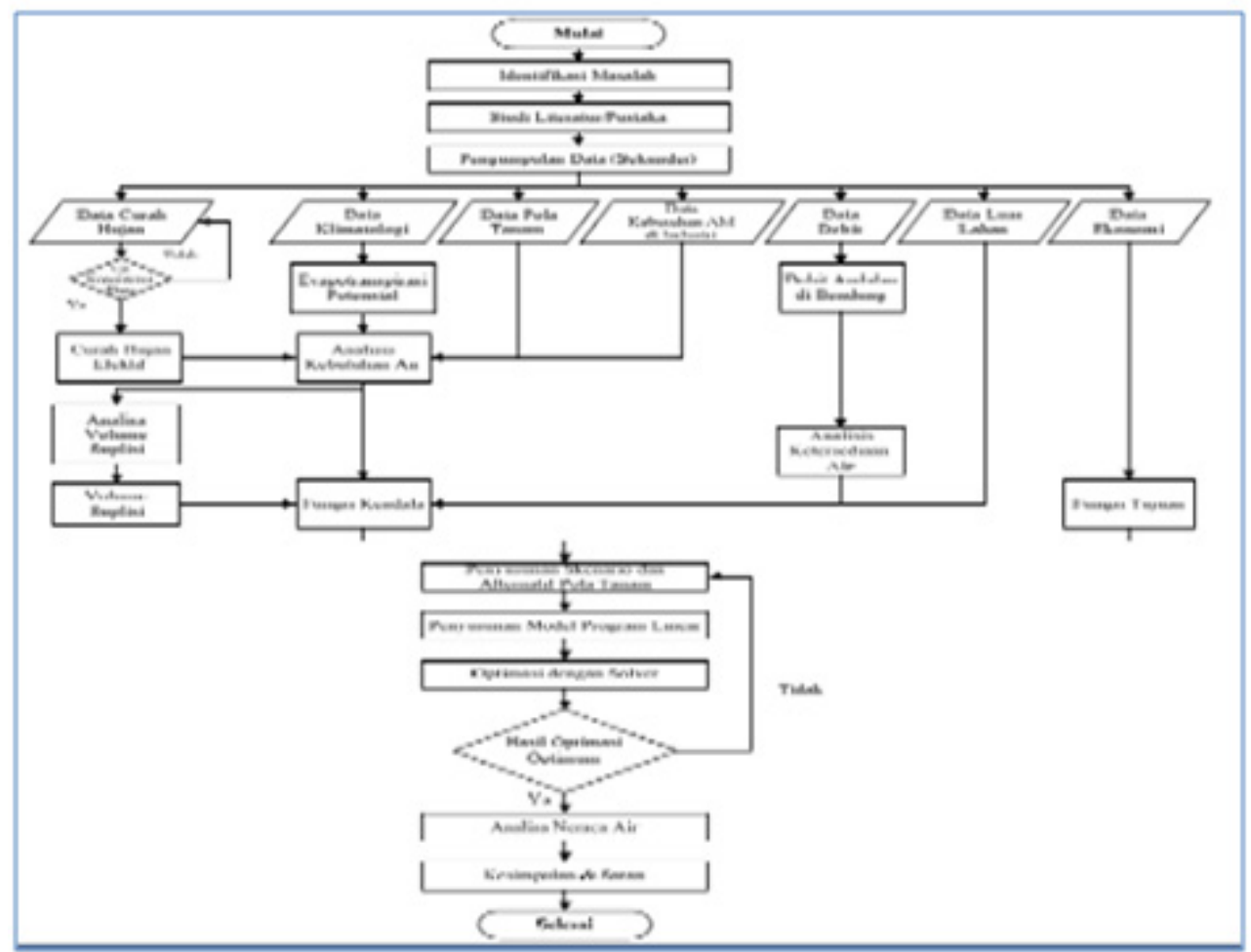

Gambar 2

Alur Pikir Penelitian

\section{Fungsi Tujuan}

Memaksimalkan $\%=\sum_{i=1}^{n} \sum_{i=1}^{m} \sum_{k=1}^{j} B_{i} \cdot X_{i j}$
$Z$ adalah Nilai yang akan dioptimalkan, yaitu memaksimalkan keuntungan pada suatu luasan lahan tertentu (daerah irigasi) dalam Rupiah (Rp), Xijka dalah Luas areal 
tanaman untuk jenis tanaman $i$, golongan $j$, musim tanam $k$ (ha), $B i$ ialah Nett benefit usahatani untuk jenis tanaman $i$ (Rp/ha).

\section{Fungsi Kendala}

Volume Ketersediaan Air:

$$
\sum_{i=1}^{n} \sum_{j=1}^{m} \sum_{k=1}^{p} v_{i j k t} \cdot X_{i j k}+\leq V_{t}
$$

Dimana vijkt adalah kebutuhan air irigasi untuk jenis tanaman $i$, golongan $j$, masa tanam $k$ pada tengah bulan $\mathrm{ke} t\left(\mathrm{~m}^{3} /\right.$ $\mathrm{dt})$, Xijk merupakan luas areal tanaman untuk jenis tanaman $i$, golongan $j$, masa tanam $k$ (ha), $V t$ adalah Ketersediaan air irigasi pada tengah bulan ke $t\left(\mathrm{~m}^{3} / \mathrm{dt}\right)$.

\section{Luas Lahan Irigasi}

$\sum_{i=1}^{b} \sum_{j=1}^{m} \sum_{k=1}^{D} X_{i j k} \leq A_{t}$

Dimana Xijk adalah uas areal tanaman untuk jenis tanaman $i$, golongan $j$, masa tanam $k$ (ha), At adalah Luas lahan daerah irigasi total (ha).

Non Negatifitas

$X_{i j k} \geq 0$
Xijk adalah luas areal tanaman untuk jenis tanaman $i$, golongan $j$, masa tanam $k$ (ha).

\section{HASIL DAN PEMBAHASAN}

Ketersediaan Air

Dalam upaya mengetahui ketersediaan air pada Daerah Irigasi Delta Brantas, dilakukan analisis debit andalan pada Bendung Lengkong. Guna mengetahui potensi debit di daerah irigasi tersebut dilakukan analisis data debit tengah bulanan di Bendung Lengkong dari tahun 2004 sampai dengan tahun 2015. Debit andalan $80 \%$ pada Bendung Lengkong untuk masing-masing periode setengah bulanan ditunjukkan pada gambardi bawah ini.

Memperhatikan gambar 3 di atas, terlihat bahwa nilai debit andalan $80 \%$ terbesar terjadi pada periode Maret I dengan nilai debit $270,01 \mathrm{~m} 3 /$ det dan untuk nilai terkecil yaitu $10,08 \mathrm{~m} 3 /$ det pada periode November I.

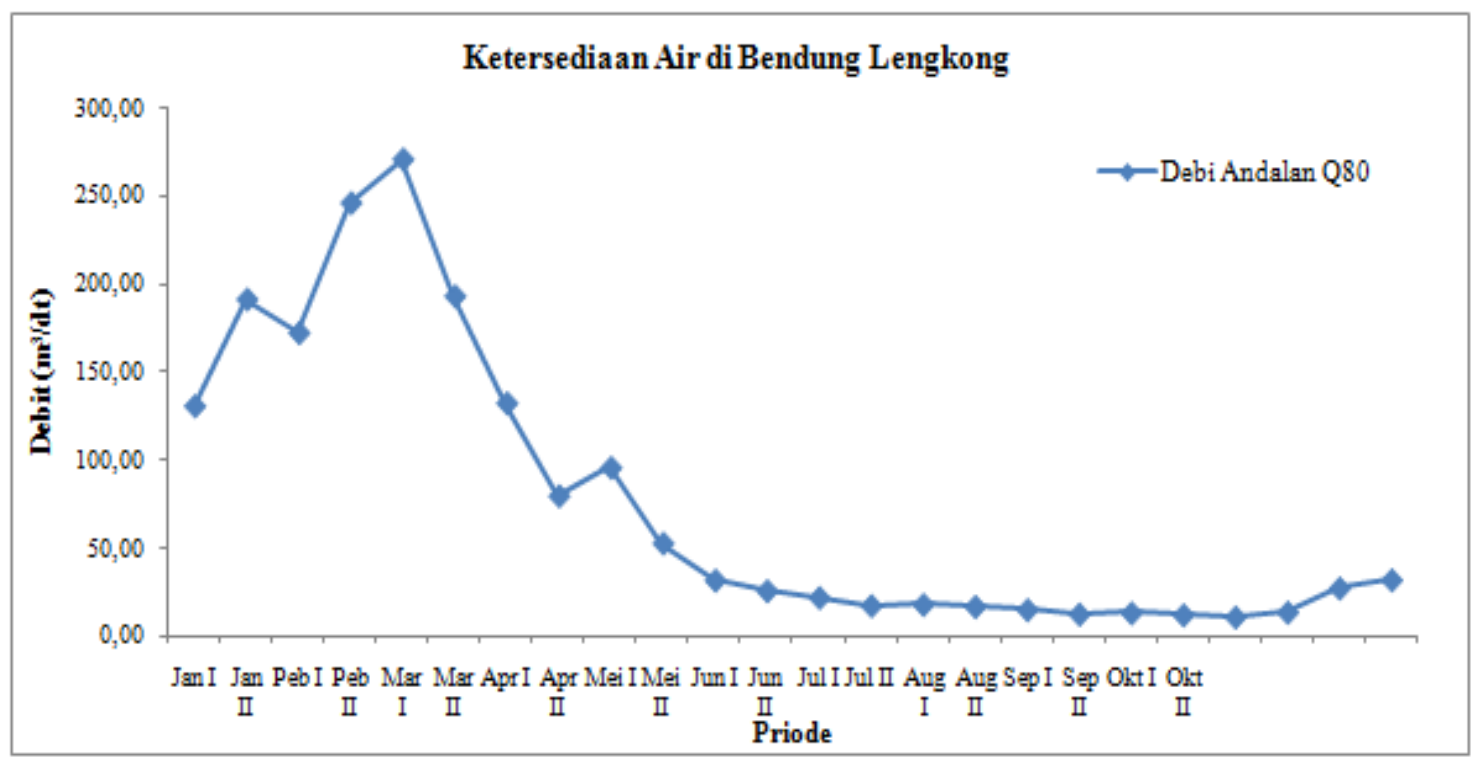

Sumber: Data Diolah

Gambar 3

Grafik Ketersediaan Air di Bendungan Lengkong 


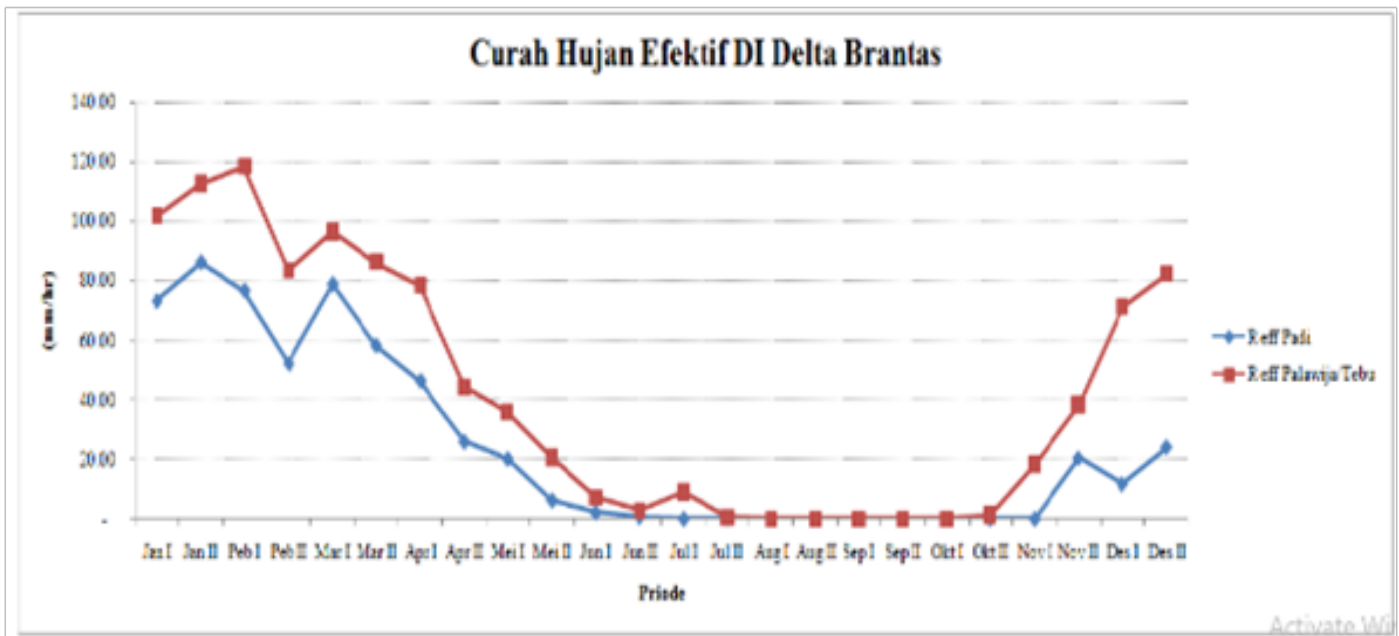

Sumber: Data Diolah

Gambar 4

Grafik Curah Hujan Efektif DI Delta Brantas

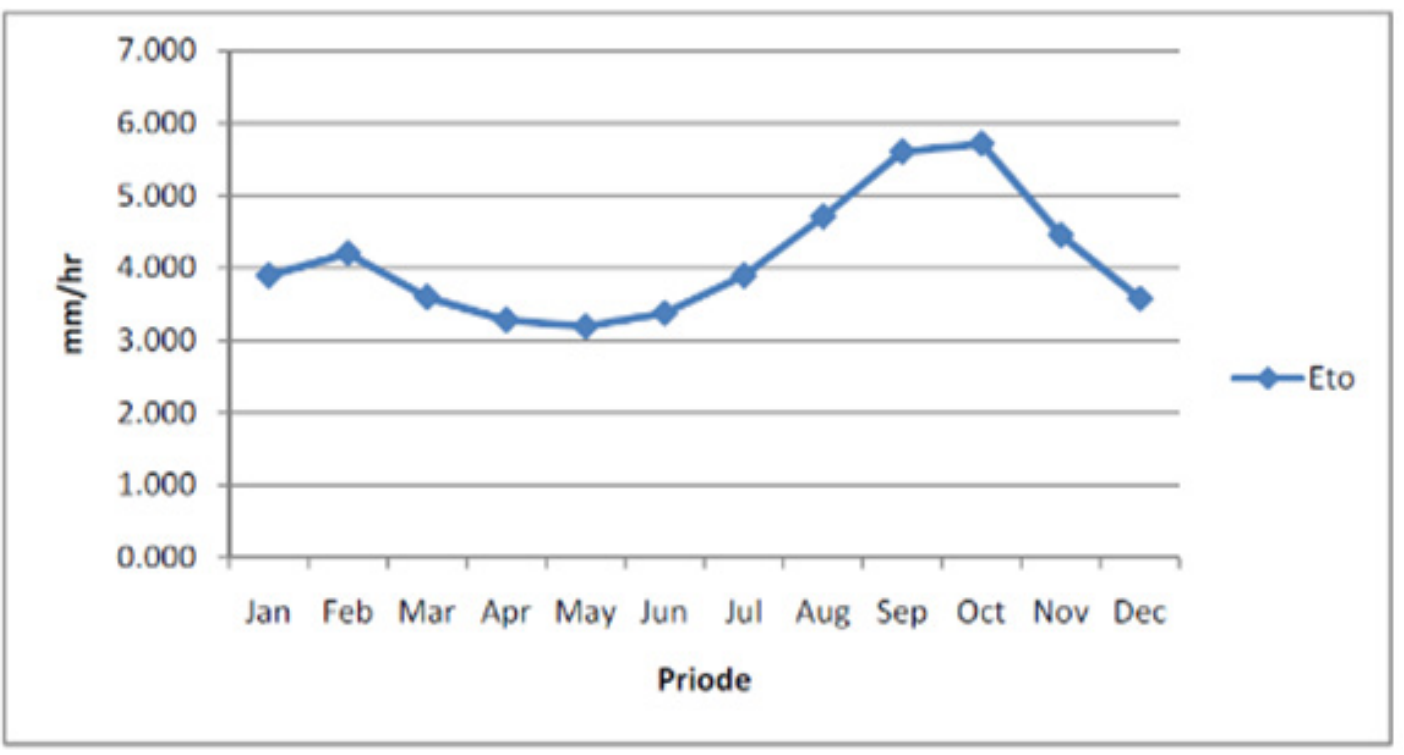

Sumber: Data Diolah

\section{Gambar 5}

Grafik Nilai Evapotranspirasi Dengan Penman Modifikasi

\section{Kebutuhan Air Irigasi}

Faktor yang mempengaruhi kebutuhan air irigasi yaitu curah hujan efektif, penggunaan konsumtif tanaman, perkolasi, penggantian lapis air atau Water Layer Replacement (WLR) dan kebutuhan air untuk penyiapan lahan sesuai dengan pola tanam yang diterapkan di daerah setempat.

Curah hujan efektif terbesar untuk tanaman padi terjadi pada bulan Januari kedua yaitu 5,75 mm/hari sedangkan curah hujan efektif terkecil terjadi padabulan Juli sampai November yaitu $0,00 \mathrm{~mm} /$ hari. Sedangkanuntuk tanaman palawija/ tebu, curah hujan efektif terbesar terjadi pada bulanJanuari kedua yaitu $7,88 \mathrm{~mm} /$ hari. Sedangkan curah hujan efektif terkecilterjadi pada terjadi pada bulan Agustus sampai Oktober yaitu $0,00 \mathrm{~mm} /$ hari. 
Evapotranspirasi tanaman acuan adalah evapotranspirasi tanaman yang dijadikan acuan, yakni rerumputan pendek. Data yang digunakan adalah data rerata setiap bulan dari tahun 2006 sampai tahun 2015 yang dikeluarkan BMKG Stasiun Meteorologi Klas I Juanda. Dataklimatologi tersebut kemudian dilakukan perhitungan evapotranspirasi dengan metode Penman Modifikasi. Hasil perhitungan tersebut sebagaimana terlihat pada gambar 5 .

Laju perkolasi sangat tergantung pada sifat-sifat tanah. Pada tanah-tanahlempung berat dengan karakteristik pengelolahan (puddling) yang baik, lajuperkolasi dapat mencapai 1-3 mm/hari. Pada tanah-tanah yang lebih ringan, laju perkolasi bisa lebih tinggi.Nilai perkolasi setiap jenis tanah sebagaimana terlihat pada tabel di bawah ini.

Tabel 1. Nilai Perkolasi Tiap Jenis Tanah

\begin{tabular}{lc}
\hline \multicolumn{1}{c}{ Tekstur Tanah } & Perkolas $(\mathbf{m m} / \mathbf{h r})$ \\
\hline Clay & $1-1,5$ \\
Silty Clay & $1,5-2$ \\
Clay Loan, Silty Clay & $2-2,5$ \\
Loan & $2,5-3$ \\
Mudy Clay Loan & $3-5$ \\
Sandy Loan & \\
\hline
\end{tabular}

Sumber: Standar Perencanaan Irigasi (KP01), 1986
Dengan ketentuan ini maka diambil nilai perkolasi pada daerah irigasi Delta Brantas sebesar $2 \mathrm{~mm} /$ hari.

Tanaman padi memerlukan penggantian lapisan air dengan urutan: (i) setelah pemupukan diusahakan menjadwalkan dan mengganti lapisan air menurut kebutuhan; (ii) jika tidak ada penjadwalan, maka dilakukan penggantian sebanyak dua kali masing-masing $50 \mathrm{~mm}$ selama sebulan dan dua bulan setelah transplantasi atau $3,3 \mathrm{~mm} /$ hari selama $1 / 2$ bulan. Berdasarkan uraian tersebut maka tinggi genangan yang diperlukan dalam studi ini sebesar $50 \mathrm{~mm}$ selama 1 bulan (30 hari), dan diberikan sebulansetelah masa transplantasi. Sehingga $\mathrm{WLR}=50 \mathrm{~mm}$ dibagi 30 hari $=$ $1,667 \mathrm{~mm} / \mathrm{hari}$

Berdasarkan hasil perhitungan penyiapan lahan, nilai penyiapan lahan berbeda setiap bulannya. Penyiapan lahan terbesar tercatat pada bulan Oktober yaitu $13,156 \mathrm{~mm} /$ hari tercatat, sedangkan terkecil tercatat pada bulan Mei sebesar 11,390 $\mathrm{mm} /$ hari. Perhitungan penyiapan lahan dalam hal ini sangat dipengaruhi besaran nilai Evapotranspirasi dan jenis tanah (perkolasi). Hasil perhitungan sebagaimana terlihat pada gambar di bawah ini.

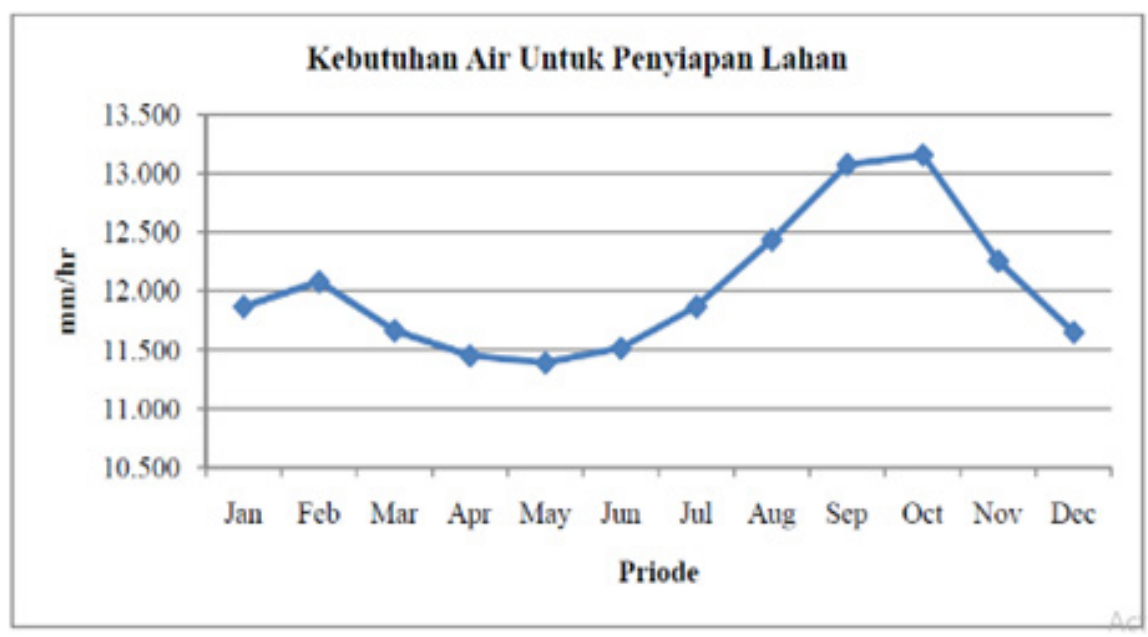

Sumber: Data Diolah

\section{Gambar 6}

Grafik Kebutuhan Air untuk Penyiapan Lahan 
Mengacu pada Standar Perencanaan Irigasi (1986) maka efisiensi irigasi secara keseluruhan diambil 90\% dan tingkat tersier $80 \%$. Angka efisiensi irigasi keseluruhan tersebut dihitung dengan cara mengkonversi efisiensi masing-masing tingkat yaitu : 0,9 x 0,9 x $0,8=0,648 \rightarrow 65 \%$. Selanjutnya dilakukan perhitungan kebutuhan air irigasi total dengan persamaan berikut :

$$
D R=\frac{(E t c+I R+W L R+P-R e)}{E i} x A
$$

Keterangan :

DR = kebutuhan air untuk irigasi (1/dtk/ ha)

Etc $=$ penggunaan air konsumtif $(\mathrm{mm} /$ hari)

IR = kebutuhan air untuk penyiapan lahan ( $\mathrm{mm} /$ hari)

WLR $=$ kebutuhan air untuk penggantian lapisan air ( $\mathrm{mm} /$ hari)

$\mathrm{P} \quad=$ kehilangan air perkolasi ( $\mathrm{mm} / \mathrm{hari})$

$\operatorname{Re}=$ curah hujan efektif (mm/hari)

$\mathrm{Ei}=$ efisiensi irigasi

A = luas areal irigasi (ha)

Hasil perhitungan kebutuhan air irigasi untuk pola tanam eksisting di daerah irigasi DAS Brantas ditampilkan pada Lampiran 1.

\section{Kebutuhan Air Untuk Minum dan Industri}

Standar kebutuhan air domestik adalah kebutuhan air bersih yang dipergunakan pada tempat-tempat hunian pribadi untuk memenuhi kebutuhan sehari-hari. Satuan yang dipakai adalah liter/orang/hari. Kondisi eksisting, kebutuhan air baku untuk PDAM untuk tahun 2014/2015 sebesar $1.150 \mathrm{l} / \mathrm{dt}$ dan untuk rencana pengembangan sebesar 165 lt/dt. Dalam studi ini data yang digunakan untuk kebutuhan air untuk industri diperoleh dari Perum Jasa Tirta I. Total kebutuhan air untuk industri sebesar $2.370,7 \mathrm{lt} / \mathrm{dt}$.

\section{Neraca Air Eksisting}

Neraca air untuk kondisi eksisting diperoleh dengan membandingkan antara kebutuhan air total (kebutuhan air irigasi ditambah kebutuhan air minum dan industri) di intake dengan ketersediaan air di bendung Lengkong. Dari grafik neraca air kondisi eksisting menunjukkan bahwa ketersediaan air di bendung Lengkong

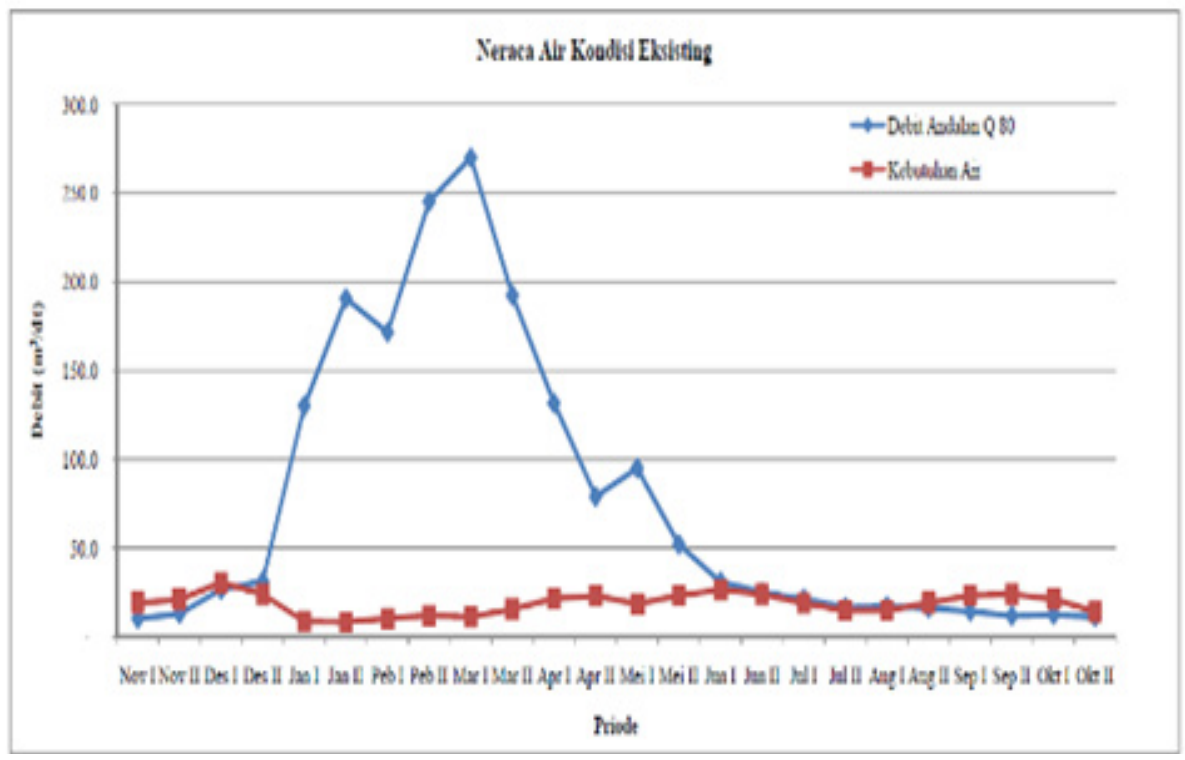

Sumber: Data Diolah

Gambar 7

Grafik Neraca Air Kondisi Eksisting 
tidak mampu memenuhi kebutuhan air (irigasi, air minum dan insustri) sepanjang tahun di daerah irigasi Delta Brantas.

Dari pola tanam eksisting pada musim tanam 2014/2015 terdapat beberapa priode yang mengalami kekurangan air.Periodeperiode yang terjadi kekurangan air sudah terjadi pada awal tanam, yaitu pada periode November I sampai Desember I. Sehingga penetapan periode awal tanam perlu ditinjau kembali. Kemudian terjadi lagi kekurangan air pada periode Agustus II sampai Oktober II.

\section{AnalisisUsahatani (Net Benefit)}

Dalam upaya mengetahui keuntungan dari suatu usahatani atau pendapatan bersih (nett benefit) dari masing-masing jenis tanaman yang diusahakan adalah dengan melakukan analisa usahatani. Analisis usahatani terdiri dari dua unsur yaitu analisis biaya produksi dan analisis pendapatan. Biaya produksi adalah biaya yang dikeluarkan pada saat proses budidaya sampai panen, biaya tersebut dapat berupa biaya pembelian benih, biaya pupuk, biaya tenaga kerja, biaya penyewaan mesin traktor, dan biaya insektisida (pengendalian hama). Sedangkan pendapatan yang diperoleh merupakan hasil kali dari total produksi dengan harga satuan komoditas yang berlaku.

Pendapatan untuk jenis tanaman padi merupakan produksi rata-rata per hektar untuk satu kali musim tanam, yaitu sebesar 7,6 ton per hekatarnya. Sedangkan harga satuannya merupakan harga yang berlaku di Kabupaten Sidoarjo tahun 2015. Selain padi, analisa usahatani juga dilakukan untuk jenis tanaman palawija(kedelai, jagung) dan tebu.

Adapun hasil perhitungan analisa usahatani untuk jenis tanaman tebu sebagaimana terlihat pada tabel 2 .

Keuntungan bersih atau nett benefitusahatani merupakan nilai manfaat air irigasi yang ditunjukkan pada tabel di atas. Harga manfaat air irigasi di daerah studi berdasarkan jenis tanaman adalah sebagai berikut : padi Rp. 15.276.000,- / ha (satu kali musim tanam selama 110-120 hari); kedelai Rp. 5.471.000,-/ha; jagung Rp.9.690.000,- /ha (satu kali musim tanam selama 80-120 hari); nett benefit rata-rata untuk palawija Rp. 7.580.500,- dan tebu Rp. 9.204.000,- (satu kali musim tanam selama 12-16 bulan).

\section{Skenario Optimasi Tata Tanam}

Skenario I Optimasi Pola Tanaman Eksisting

Pada skenario I ini pola tanaman yang digunakan adalah pola tanam eksisting dengan mensimulasikan perubahan jadwal tanam. Karena diketahui pada pembahasan sebelumnya awal tanam untuk kondisi eksisting sudah terjadi kekurangan air. Luas tanaman tebu untuk skenario I adalah seluas 6.271 ha,. Untuk skenario I dilakukan simulasi dengan 4 (empat) alternatif jadwal tanam. Selanjutnya masing-masing alternatif dioptimasi agar memberikankeputusan luas tiap jenis tanaman pada suatu musim tanam agar tercapai benefit yang paling optimum. Optimasi pola tanam dengan simulasi jadwal tanam, meliputi :

a) Alternatif 1 : awal tanam November I

MT 1 : November I - Pebruari I

MT 2 : Maret I - Juni II

MT 3 : Juli II - Oktober I

b) Alternatif 1 : awal tanam November II

MT 1 : November II - Maret I

MT 2 : Maret II - Juli I

MT 3 : Agustus I - Oktober II

c) Alternatif 2 : awal tanam Desember I

MT 1 : Desember I - Maret II

MT 2 : April I - Juli II

MT 3 : Agustus II - November I

d) Alternatif 3 : awal tanam Desember II

MT 1 : Desember II - April I

MT 2 : April II -Agustus I

MT 3 : September I - November II 
Tabel 2. Analisa Usahatani Tebu per Hektar

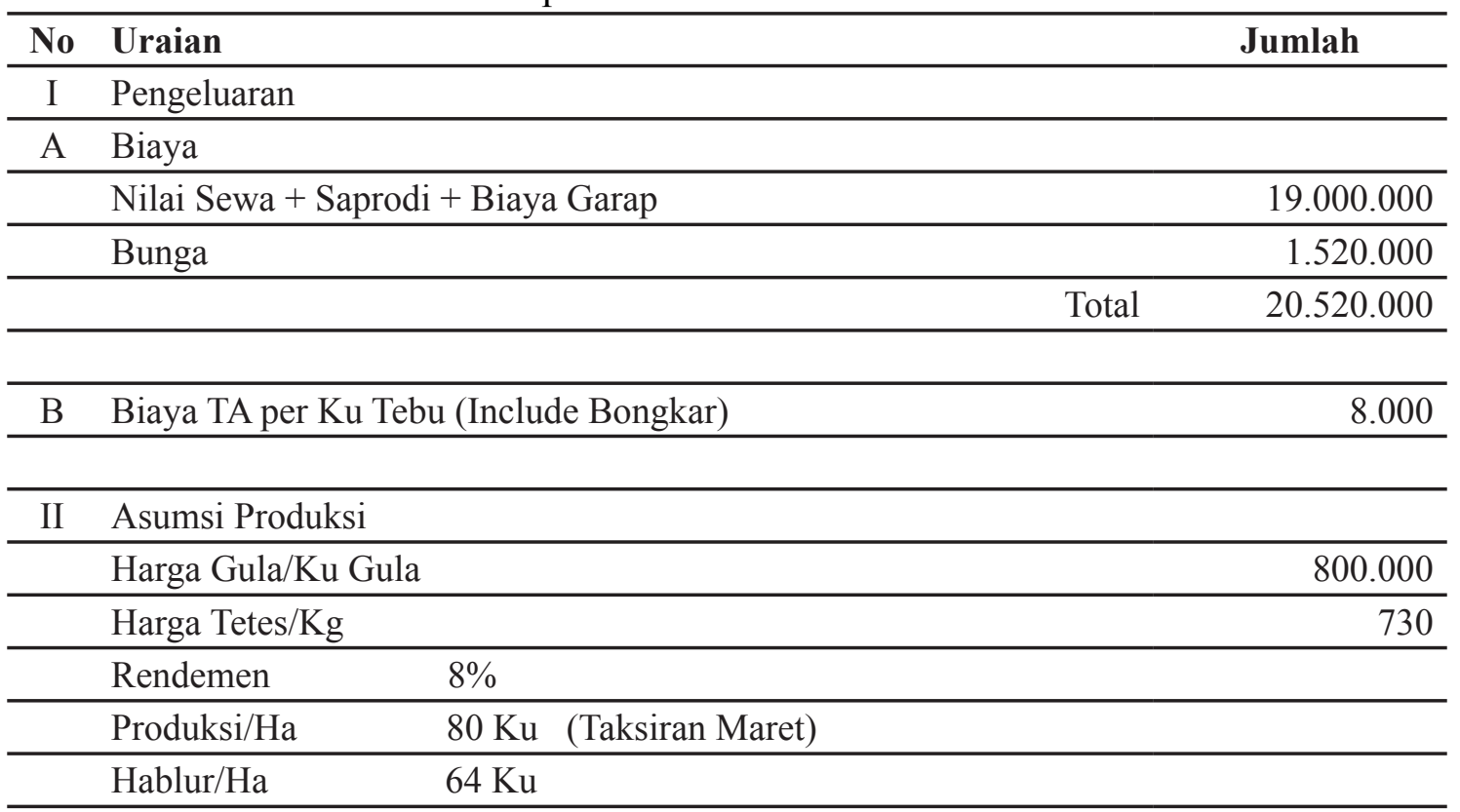

\begin{tabular}{|c|c|c|c|}
\hline III & Nilai/Harga Tebu per $\mathrm{Ku}$ & & \\
\hline \multirow[t]{4}{*}{ A } & Nilai Kotor (Bruto) & & \\
\hline & $5,36 \% \times 1,002 \times 800.000$ & & 42.966 \\
\hline & Unsur Tetes & & 2.190 \\
\hline & & Nilai Total Kotor & 45.156 \\
\hline \multirow[t]{2}{*}{$\mathrm{B}$} & Nilai Bersih (Netto) & & \\
\hline & Nilai Tebu Kotor - Biaya TA & & 37.156 \\
\hline IV & Pencapaian BEP & & \\
\hline \multirow[t]{2}{*}{ A } & Jumlah Biaya (I.A) : Nilai Tebu Bersih (III.B) & per $\mathrm{Ku}$ & 552 \\
\hline & Pendapatan/SHU ((II.A-IV.A)xIII.B) & & 9.204 .608 \\
\hline
\end{tabular}

Sumber : Data Diolah

Skenario II Optimasi Pola Tanam beroperasi lagi sejak Agustus 2016, Kondisi Tanaman Tebu $\mathbf{5 . 2 5 8}$ ha sehingga petani kurang begitu bergairah Berdasarkan realisasi tanam, luas lahan tanaman tebu selama 5 tahun terakhir terus menurun. Pada musim tanam 2014/2015 luas tanam yang terealisasi 5.258 ha dari rencana tanam seluas 6.271 ha (Dinas Pertanian Kabupaten Sidoarjo). Ini diakibatkan beberapa faktor diantaranya rencana penutupan 2 (dua) pabrik gula yang ada di Kabupaten Sidoarjo yaitu PG Toelangan dan PG Watoetoelis pada tahun 2017 oleh PTPN X. Walau belum lagi untuk menanam tebu.

\section{Skenario III Optimasi Pola Tanam}

Optimasi pola tanam pada skenario III, diasumsikan bahwa luas tanaman padi, palawija dan tebu tidak saling terikat, atau 3 (tiga) jenis tanaman tersebut ditanam secara bebas. Agar memberikan benefit yang optimum, perlu dilakukan optimasi luas tiap jenis tanaman disetiap musim tanam. 
Skenario IV Optimasi Dengan Penambahan Debit Suplisi

Optimasi pada skenario IV, dilakukan penambahan debit suplisi dari kelebihan air pada pola tanam eksisting sebesar 5,102 $\mathrm{m} 3 /$ dt. Dengan penambahan debit suplisi itu diharapkan diperoleh benefit yang optimum

\section{Analisa Neraca Air Kondisi Optimum}

Analisis neraca air dimaksudkan untuk membandingkan antara ketersediaan air dengan kebutuhan air irigasi di daerah irigasi Delta Brantas. Ketersediaan air merupakan debit andalan (Q80) di bendung Lengkong, sedangkan kebutuhan air dihitung berdasarkan pola tanam pada daerah irigasi.

a. Neraca Air Skenario I Dengan Pola Tanam Eksisting

Pada skenario ini keuntungan optimum diperoleh dari pola tanam alternatif 2 dengan awal tanam dimulai pada November II. Dari grafik neraca air seperti pada gambar 5.11, menunjukkan kebutuhan puncak terjadi pada periode Desember II sebesar 28,35 m3/det dan kebutuhan air paling kecil pada periode Januari I dan Maret I sebesar 7,17 m3/ det.

b. Neraca Air Skenario II Dengan Pengurangan Luas Tanaman Tebu

Pada Skenario II luas tanaman tebu dibatasi dengan luas sesuai dengan realisasi tanam tahun 2014/2015 seluas 5258 ha. Pada skenario ini keuntungan optimum diperoleh dari pola tanam alternatif 2 dengan awal tanam dimulai pada November II. Dari grafik neraca air seperti pada gambar 5.12, menunjukkan kebutuhan puncak terjadi pada periode Desember II sebesar 29,47 m3/det dan kebutuhan air paling kecil pada periode Januari I sebesar 7,33 m3/det

c. Neraca Air Skenario III Dengan Pola Tanam Bebas

Pada skenario III setiap jenis tanaman tidak diberikan batasan luas tanam. Pada skenario ini keuntungan optimum diperoleh dari pola tanam alternatif 3 dengan awal tanam dimulai pada Desember I. Namun intensitas tanam tertinggi terjadi pada alternatif 2 dengan awal tanam November II. Dari grafik neraca air seperti pada gambar 5.13 dan 5.14, menunjukkan kebutuhan puncak untuk alternatif 3 terjadi pada periode Desember II sebesar 25,78 m3/ det dan kebutuhan air paling kecil pada periode November II sebesar 3,69 m3/ det. Sedangkan untuk alternatif 2 terjadi pada periode Desember II sebesar 31,19 m3/det dan kebutuhan air paling kecil pada periode November I sebesar 4,23 $\mathrm{m} 3 /$ det.

d. Neraca Air Skenario IV Dengan Suplisi Pada skenario IV pola tanam kondisi eksisting mendapatkan penambahan debit suplesi dari kelebihan air di lahan sebesar 4,92 m3/dt. Pada skenario ini keuntungan optimum diperoleh dari pola tanam alternatif 2 dengan awal tanam dimulai pada November II. Dari grafik neraca air seperti pada gambar 5.15, menunjukkan kebutuhan puncak terjadi pada periode Desember II sebesar 28,74 m3/det dan kebutuhan air paling kecil pada periode Januari II sebesar 7,38 m3/det.

\section{Hasil Optimasi}

Dalam upaya mengatasi masalah kekurangan air pada Daerah Irigasi Delta Brantas, dengan melakukan analisis optimasi pengaturan pola tanam sesuai ketersediaan air yang berasal dari bendung Lengkong. Dalam studi ini terdapat empat skenario dengan masing-masing skenario terdapat empat alternatif. Dari penyelesaian optimasi dengan program linier pada masing-masing skenario didapatkan luas tanam sehingga dapat diketahui keuntungan hasil pertanian dari penerapan pola tanam tersebut. 
Skenario I Dengan Pola Tanam Eksisting Dari hasil optimasi pada skenario I dengan pola tanam eksisting diperoleh hasil sebagai berikut untuk masing-masing alternatif.

Pada skenario I ini luas dan intensitas tanam terbesar diperoleh pada alternatif 2 sebesar $223,50 \%$ dengan awal tanam November II, sedangkan untuk luas tanam padi terbesar pada alternatif 2 seluas 27.120 Ha. Dengan hasil tersebut diperoleh keuntungan terbesar padaalternatif 2 sebesar Rp. 496.270.874.780,- atau naik sebesar $0,67 \%$ dari keuntungan yang diperoleh dari realisasi tanam tahun 2014/2015. Keuntungan terendah terjadi pada alternatif IV sebesar Rp. 422.326.930.286,-.

\begin{tabular}{|c|c|c|c|c|c|c|}
\hline \multirow{2}{*}{ Alternatif } & \multirow{2}{*}{ Uraian } & \multicolumn{4}{|c|}{ Luas Tanam (Ha) } & \multirow{2}{*}{$\begin{array}{l}\text { Intensitas } \\
\text { Tanam (\%) }\end{array}$} \\
\hline & & Padi & Palawija & Tebu & Total & \\
\hline \multirow{4}{*}{$\begin{array}{c}\text { Alternatif I } \\
\text { (Awal Tanam } \\
\text { November I) }\end{array}$} & MT I (Nov I - Peb II) & 11,046 & 0 & 6,271 & 17,317 & 78.77 \\
\hline & MT II (Mar I - Jun II) & 15,713 & 0 & 6,271 & 21,984 & 100.00 \\
\hline & MT III (Jul I - Okt II) & 0 & 3,312 & 6,271 & 9,583 & 43.59 \\
\hline & Total & 26,759 & 3,312 & 6,271 & 48,884 & 222.36 \\
\hline \multirow{4}{*}{$\begin{array}{l}\text { Alternatif II } \\
\text { (Awal Tanam } \\
\text { November II) }\end{array}$} & MT I (Nov II - Mar I) & 15,127 & 91 & 6,271 & 21,489 & 97.75 \\
\hline & MT II (Mar II - Jui I) & 11,993 & $\cdot$ & 6,271 & 18,264 & 83.08 \\
\hline & MT III (Jul II - Nov I) & 0 & 3,110 & 6,271 & 9,381 & 42.67 \\
\hline & Total & 27,120 & 3,201 & 6,271 & 49,134 & 223.50 \\
\hline \multirow{4}{*}{$\begin{array}{l}\text { Alternatif III } \\
\text { (Awal Tanam } \\
\text { Desember I) }\end{array}$} & MT I (Des I - Mar II) & 15,622 & 91 & 6,271 & 21,984 & 100.00 \\
\hline & MT II (Apr I - Jui II) & 8,713 & - & 6,271 & 14,984 & 68.16 \\
\hline & MT III (Aug I - Nov II) & 0 & 3,779 & 6,271 & 10,050 & 45.72 \\
\hline & Total & 24,335 & 3,870 & 6,271 & 47,019 & 213.88 \\
\hline \multirow{4}{*}{$\begin{array}{l}\text { Alternatif IV } \\
\text { (Awal Tanam } \\
\text { Desember II) }\end{array}$} & MT I (Des II - Apr I) & 15,713 & - & 6,271 & 21,984 & 100.00 \\
\hline & MT II (Apr II - Aug I) & 6,282 & - & 6,271 & 12,553 & 57.10 \\
\hline & MT III (Aug II - Des I) & 0 & 3,775 & 6,271 & 10,046 & 45.69 \\
\hline & Total & 21,995 & 3,775 & 6,271 & 44,582 & 202.79 \\
\hline
\end{tabular}

Sumber: Data Diolah

\section{Gambar 8}

\section{Hasil Luas dan Intensitas Tanam Optimasi Skenario I}

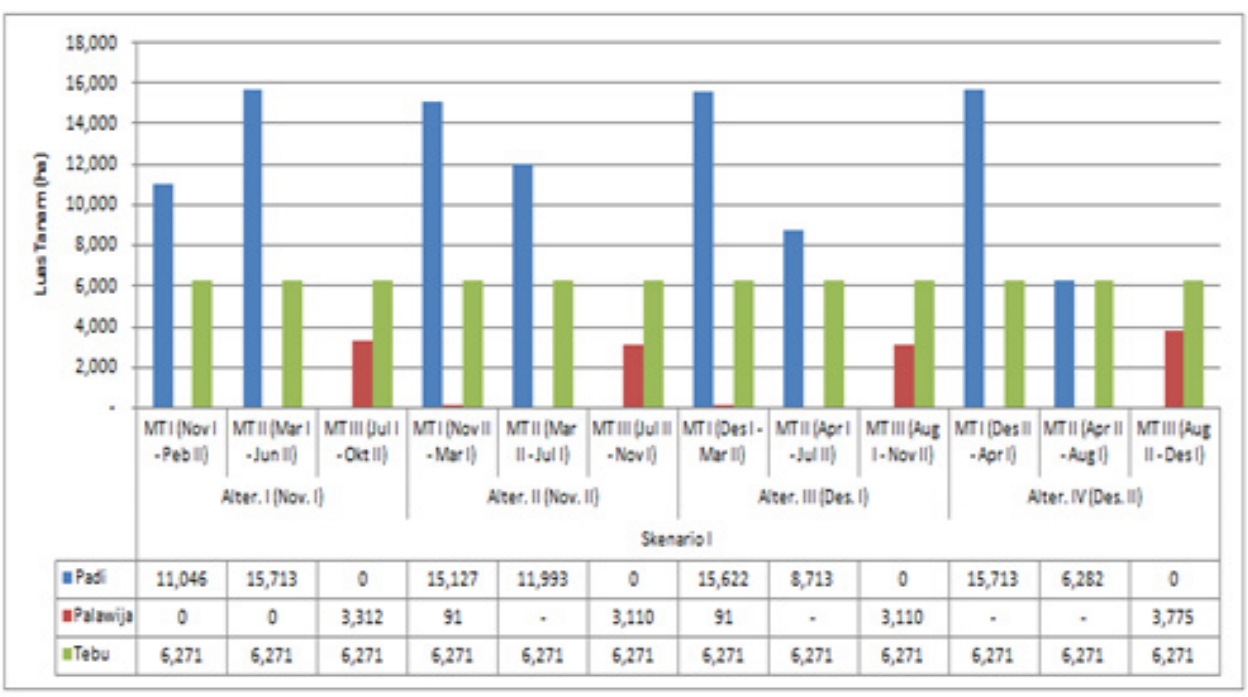

Sumber: Data Diolah

Gambar 9

Perhitungan Benefit Skenario I 


\begin{tabular}{|c|c|c|c|c|c|}
\hline \multirow{2}{*}{ Alternatif } & \multirow{2}{*}{ Uraian } & \multicolumn{4}{|c|}{ Keuntungan Hasil Pertanian (Rp./Tahun) } \\
\hline & & Padi & Palawija & Tebu & Total \\
\hline \multirow{4}{*}{$\begin{array}{l}\text { Alternatif I } \\
\text { (Awal Tanam } \\
\text { November I) }\end{array}$} & MT I (Nov I - Peb II) & $168,738,576,805$ & 0 & \multirow{3}{*}{$57,722,096,768$} & $168,738,576,805$ \\
\hline & MT II (Mar I - Jun II) & $240,031,788,000$ & 0 & & $240,031,788,000$ \\
\hline & MT III (Jul I - Okt II) & $=$ & $25,109,838,281$ & & $82,831,935,049$ \\
\hline & Total & $408,770,364,805$ & $25,109,838,281$ & $57,722,096,768$ & $491,602,299,853$ \\
\hline \multirow{4}{*}{$\begin{array}{l}\text { Alternatif II } \\
\text { (Awal Tanam } \\
\text { November II) }\end{array}$} & MT I (Nov II - Mar I) & $231,079,932,805$ & $689,825,500$ & \multirow{3}{*}{$57,722,096,768$} & $231,769,758,305$ \\
\hline & MT II (Mar II - Jui I) & $183,206,518,465$ & - & & $183,206,518,465$ \\
\hline & MT III (Jul II - Nov I) & - & $23,572,501,243$ & & $81,294,598,011$ \\
\hline & Total & $414,286,451,269$ & $24,262,326,743$ & $57,722,096,768$ & $496,270,874,780$ \\
\hline \multirow{4}{*}{$\begin{array}{l}\text { Alternatif III } \\
\text { (Awal Tanam } \\
\text { Desember I) }\end{array}$} & MT I (Des I - Mar II) & $238,641,672,000$ & $689,825,500$ & \multirow{3}{*}{$57,722,096,768$} & $239,331,497,500$ \\
\hline & MT ॥ (Apr I - Jui II) & $133,106,920,696$ & - & & $133,106,920,696$ \\
\hline & MT III (Aug I - Nov II) & - & $28,647,761,113$ & & $86,369,857,881$ \\
\hline & Total & $371,748,592,696$ & $29,337,586,613$ & $57,722,096,768$ & $458,808,276,077$ \\
\hline \multirow{4}{*}{$\begin{array}{l}\text { Alternatif IV } \\
\text { (Awal Tanam } \\
\text { Desember II) }\end{array}$} & MT I (Des II - Apr I) & $240,031,788,000$ & $\cdot$ & \multirow{3}{*}{$57,722,096,768$} & $240,031,788,000$ \\
\hline & MT II (Apr II - Aug I) & $95,960,189,329$ & - & & $95,960,189,329$ \\
\hline & MT III (Aug II - Des I) & - & $28,612,856,189$ & & $86,334,952,957$ \\
\hline & Total & $335,991,977,329$ & $28,612,856,189$ & $57,722,096,768$ & $422,326,930,286$ \\
\hline
\end{tabular}

Sumber: Data Diolah

Gambar 10

Perhitungan Benefit Skenario I

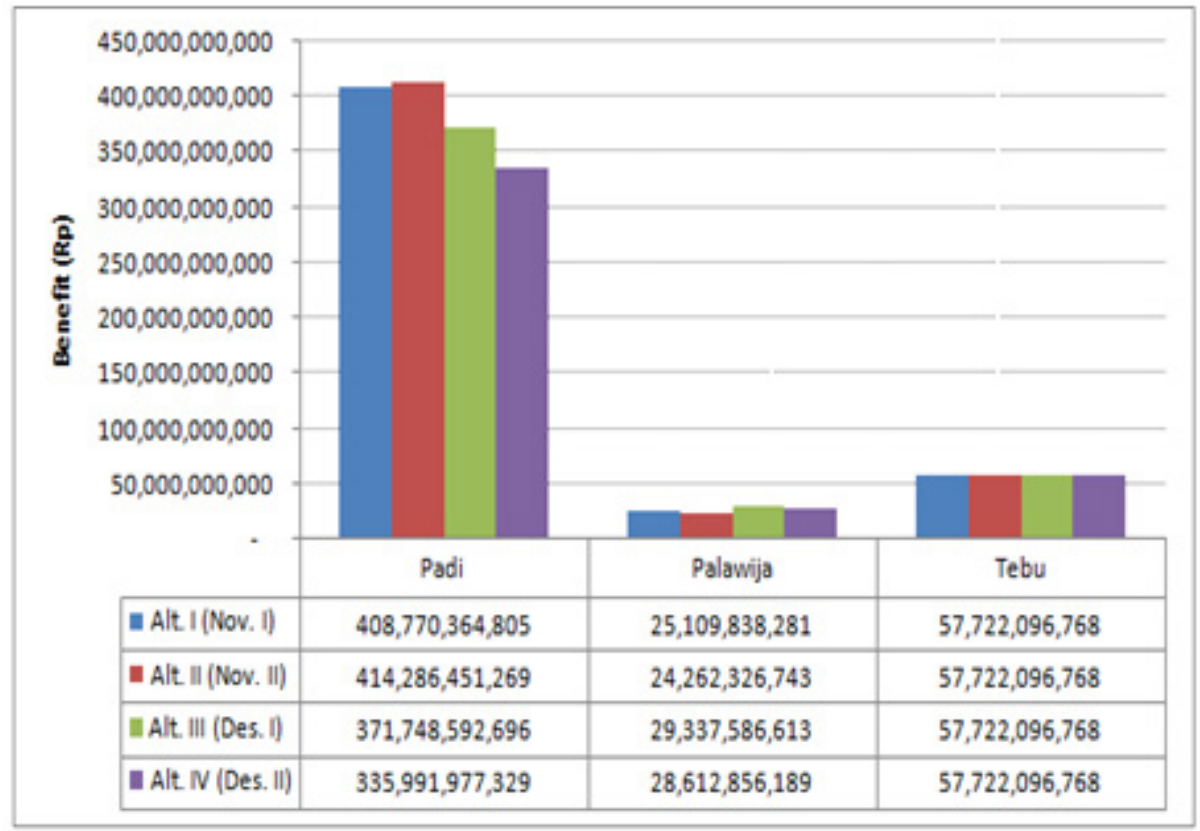

Sumber: Data Diolah

\section{Gambar 11}

\section{Perhitungan Benefit Skenario I}

Skenario II Dengan Pola Tanam dari 6.271 ha menjadi 5.258 ha, diperoleh Pengurangan Luas Lahan Tebu hasil sebagai berikut untuk masing-masing Dari hasil optimasi pada skenario II dengan alternatif. pola tanam pengurangan luas tanam tebu 


\begin{tabular}{|c|c|c|c|c|c|c|}
\hline \multirow{2}{*}{ Alternatif } & \multirow{2}{*}{ Uraian } & \multicolumn{4}{|c|}{ Luas Tanam ( $\mathrm{Ha}$ ) } & \multirow{2}{*}{$\begin{array}{l}\text { Intensitas } \\
\text { Tanam (\%) }\end{array}$} \\
\hline & & Padi & Palawija & Tebu & Total & \\
\hline \multirow{4}{*}{$\begin{array}{c}\text { Alternatifl } \\
\text { (Awal Tanam } \\
\text { November I) }\end{array}$} & MTI (Nov I- Peb II) & 11,597 & 0 & \multirow{3}{*}{5,258} & 6,855 & 76.67 \\
\hline & MT II (Mar I - Jun II) & 16,726 & 0 & & 21,984 & 100.00 \\
\hline & MT III (Jul I - Okt II) & 0 & 4,193 & & 9,451 & 42.99 \\
\hline & Total & 28,323 & 4,193 & 5,258 & 48,290 & 219.66 \\
\hline \multirow{4}{*}{$\begin{array}{l}\text { Alternatif II } \\
\text { (Awal Tanam } \\
\text { November II) }\end{array}$} & MTI (Now II - Mar I) & 15,940 & 97 & \multirow{3}{*}{5,258} & 21,295 & 96.87 \\
\hline & MT II (Mar II - Jui I) & 12,699 & - & & 17,957 & 81.68 \\
\hline & MT III (JuI II - Nov I) & 0 & 3,937 & & 9,195 & 41.82 \\
\hline & Total & 28,639 & 4,033 & 5,258 & 48,447 & 220.37 \\
\hline \multirow{4}{*}{$\begin{array}{l}\text { Alternatif III } \\
\text { (Awal Tanam } \\
\text { Desember I) }\end{array}$} & MTI (Des & 16,629 & 97 & \multirow{3}{*}{5,258} & 21,984 & 100.00 \\
\hline & MT II (Apr I - Jui II) & 9,419 & - & & 14,677 & 66.76 \\
\hline & MT III (Aug I - Nov II) & 0 & 4,484 & & 9,742 & 44.31 \\
\hline & Total & 26,048 & 4,581 & 5,258 & 46,403 & 211.08 \\
\hline \multirow{4}{*}{$\begin{array}{l}\text { Alternatif IV } \\
\text { (Awal Tanam } \\
\text { Desember II) }\end{array}$} & MTI (Des II - Apr I) & 16,726 & - & \multirow{3}{*}{5,258} & 21,984 & 100.00 \\
\hline & MT II (Apr II - Aug I) & 6,831 & - & & 12,099 & 54.99 \\
\hline & MT III (Aug II - Des I) & 0 & 4,395 & & 9,653 & 43.91 \\
\hline & Total & 23,557 & 4,395 & 5,258 & 43,725 & 198.90 \\
\hline
\end{tabular}

Sumber: Data Diolah

Gambar 12

Hasil Luas dan Intensitas Tanam Optimasi Skenario II

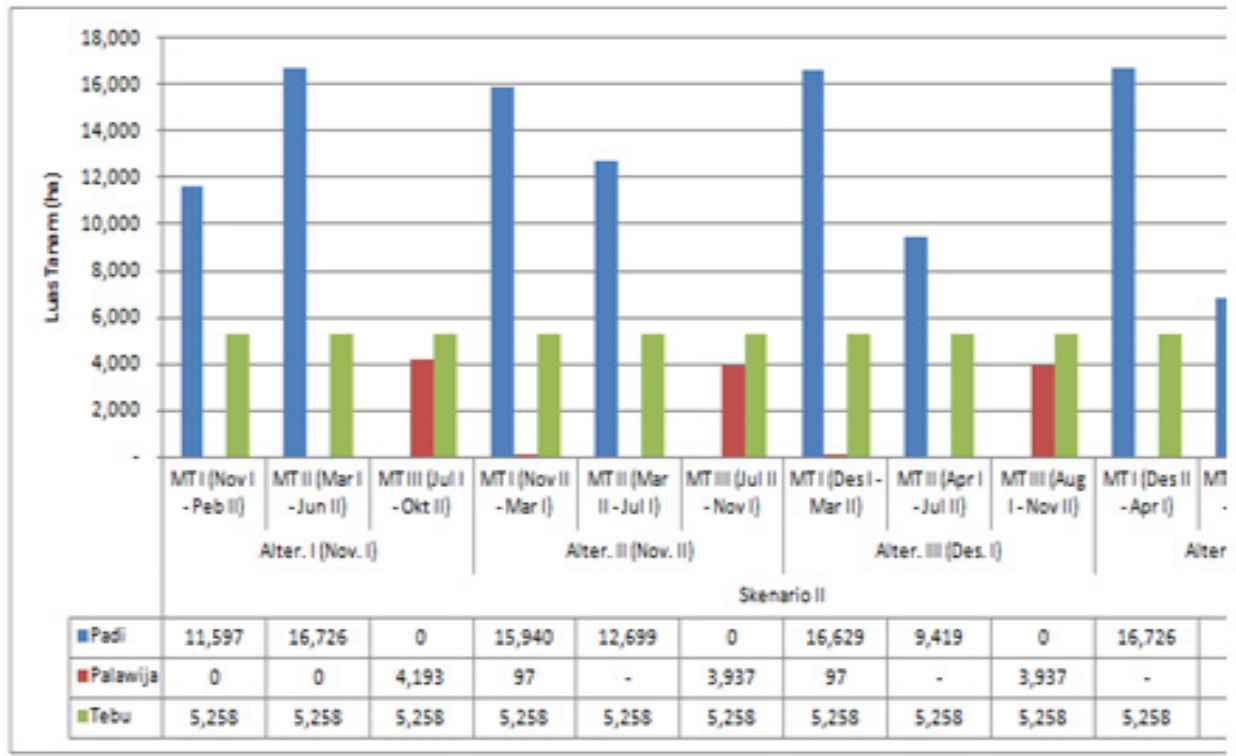

Sumber : Data Diolah

\section{Gambar 13}

\section{Luas Tanam Optimasi Skenario II}

Pada skenario II ini luas dan alternatif 2 sebesar Rp. 516.466.866.936,intensitas tanam terbesar diperoleh pada atau naik sebesar $4,55 \%$ dari keuntungan alternatif 2 sebesar $220,37 \%$ dengan awal yang diperoleh dari realisasi tanam tahun tanam November II, sedangkan untuk 2014/2015. Sedangkan keuntungan luas tanam padi terbesar pada alternatif 2 terendah terjadi pada alternatif IV sebesar seluas 28.639 Ha. Dengan hasil tersebut Rp. 441.564.366.602,-.

diperoleh keuntungan terbesar pada 


\begin{tabular}{|c|c|c|c|c|c|}
\hline \multirow{2}{*}{ Alternatif } & \multirow{2}{*}{ Urian } & \multicolumn{4}{|c|}{ Keuntungan Hassil Pertaniza (Rp,/Tahun) } \\
\hline & & Padi & Palawija & Tebu & Total \\
\hline \multirow{4}{*}{$\begin{array}{l}\text { Altematifl } \\
\text { (Awal Tanam } \\
\text { November I) }\end{array}$} & MTII(NovI-Pebl) & $177,153,887,492$ & 0 & \multirow{3}{*}{$48,397,828,854$} & $177,153,887,492$ \\
\hline & MTII(MarI-Jun II) & $255,506,376,000$ & 0 & & $255,506,376,000$ \\
\hline & MT II (jul I-Oktli) & - & $31,786,724,361$ & & $80,184,553,226$ \\
\hline & Total & $432,660,263,-492$ & $31,786,724,361$ & $48,397,828,854$ & $512,84,816,717$ \\
\hline \multirow{4}{*}{$\begin{array}{l}\text { Alternatif II } \\
\text { (Awal Tanam } \\
\text { November II) }\end{array}$} & MTI $[$ Nov $\| \cdot \operatorname{Mar} 1)]$ & $23,506,642,677$ & $734,297,799$ & \multirow{3}{*}{$48,397,828,854$} & $24,240,940,476$ \\
\hline & MTII (Marll|Juil) & $193,966,986,965$ & . & & $193,986,986,965$ \\
\hline & MT III (Jul II - Nov I) & - & $29,841,110,631$ & & $78,238,939,455$ \\
\hline & Total & $437,493,623,642$ & $30,5 \pi 5,408,430$ & $48,397,828,854$ & $516,456,866,936$ \\
\hline \multirow{4}{*}{$\begin{array}{l}\text { Alternatif III } \\
\text { (Awal Tanam } \\
\text { Desember I) }\end{array}$} & MTI (DesI-Nari) & $254,026,640,735$ & $734,297,799$ & \multirow{3}{*}{$48,397,828,864$} & $254,760,938,534$ \\
\hline & $\operatorname{MT} \|(A \mathrm{P}$ & $143,887,399,196$ & . & & $143,887,309,196$ \\
\hline & MT III (Aug I - Nov II) & . & $33,950,050,613$ & & $82,387,879,477$ \\
\hline & Total & $397,914,029,932$ & $34,724,348,412$ & $48,397,828,864$ & $481,036,207,208$ \\
\hline \multirow{4}{*}{$\begin{array}{l}\text { Alternatif } N \\
\text { (Awal Tanam } \\
\text { Desember II) }\end{array}$} & MTI (Des $\| \cdot$ AprII) & $255,506,376,000$ & . & \multirow{3}{*}{$48,397,828,864$} & $255,506,376,000$ \\
\hline & bl) & $104,345,848,508$ & . & & $104,345,848,508$ \\
\hline & MTI & & $33,314,313,230$ & & $81,712,142,094$ \\
\hline & Total & $359,852,224,508$ & $33,314,313,230$ & $48,397,828,854$ & $441,564,366,6002$ \\
\hline
\end{tabular}

Sumber: Data Diolah

Gambar 14

Perhitungan Benefit Skenario II

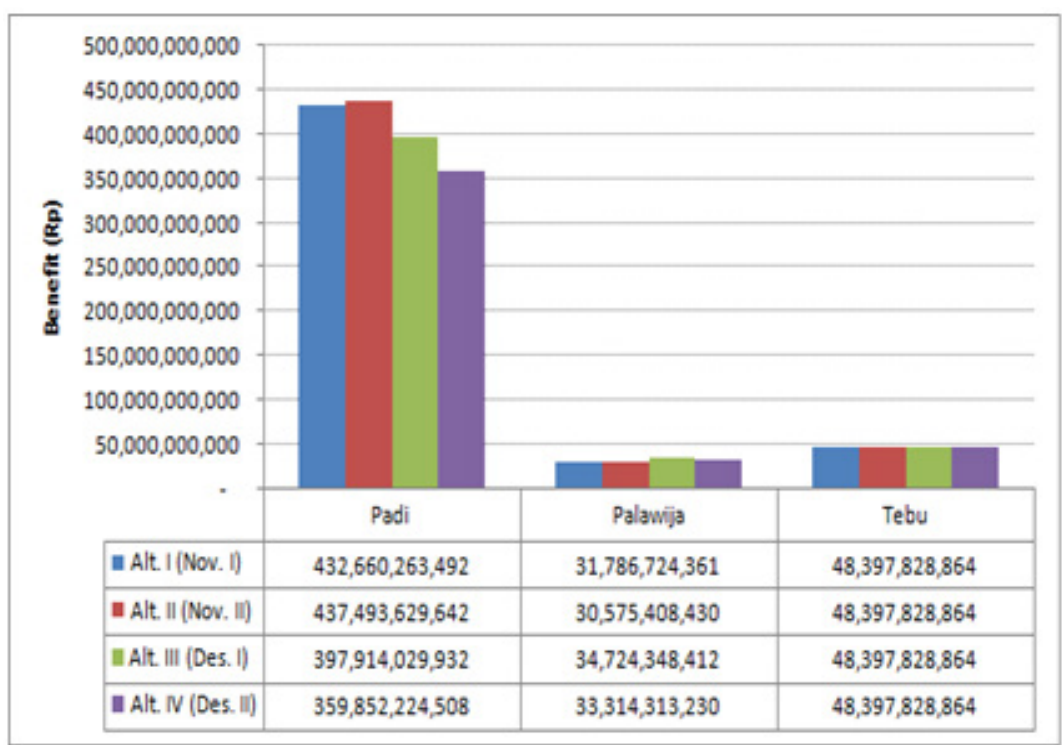

Sumber: Data Diolah

Gambar 15

Perhitungan Benefit Skenario II

Skenario III Dengan Pola Tanam Bebas

Dari hasil optimasi pada skenario III dengan pola tanam bebas (tidak terikat satu sama lain), diperoleh hasil sebagai berikut untuk masing-masing alternatif.

Pada skenario III ini luas dan alternatif 2 sebesar $230,42 \%$ dengan awal tanam November II, sedangkan untuk luas tanam padi terbesar pada alternatif 3 seluas $30.370 \mathrm{Ha}$ dengan awal tanam Desember I. Dengan hasil tersebut diperoleh keuntungan terbesar pada alternatif 3 sebesar Rp. 600.433.180.705,- 
atau naik sebesar $17,9 \%$ dari keuntungan yang diperoleh dari realisasi tanam tahun 2014/2015. Sedangkan keuntungan terendah terjadi pada alternatif 1 sebesar Rp. 491.609.362.779,--

Skenario III terlihat memberikan keuntungan optimasi paling tinggi jika dibandingkan dengan dua skenario sebelumnya. Keuntungan tersebut dapat dicapai dengan memaksimalkan penanaman padi dan palawija serta mengabaikan tebu. Temuan ini sejalan dengan beberapa studi yang menerapkan pola tanam padipalawija untuk memperoleh optimasi yang

\begin{tabular}{|c|c|c|c|c|c|}
\hline \multirow{2}{*}{ Alternatif } & \multirow{2}{*}{ Uriálan } & \multicolumn{4}{|c|}{ Keuntungan Hasil Pertanian (Rp./Tahun] } \\
\hline & & Padi & Palswija & Tebu & Total \\
\hline \multirow{4}{*}{$\begin{array}{l}\text { Alternatif। } \\
\text { (Awal Tanam } \\
\text { November I) }\end{array}$} & MTI(Nov I- Peb II) & $177,153,887,492$ & 0 & \multirow{3}{*}{$48,397,828,864$} & $177,153,887,492$ \\
\hline & MT II (Mar 1-Jun II) & $255,506,376,000$ & 0 & & $255,506,376,000$ \\
\hline & MT III (lul I- Okt II) & . & $31,785,724,361$ & & $80,184,553,225$ \\
\hline & Total & $432,660,263,492$ & $31,786,724,361$ & $48,397,828,854$ & $512,844,816,717$ \\
\hline \multirow{4}{*}{$\begin{array}{l}\text { Alternatif II } \\
\text { (Awal Tanam } \\
\text { November II] }\end{array}$} & MTI (Nov II- Marl) & $243,506,642,677$ & $734,297,799$ & \multirow{3}{*}{$48,397,828,854$} & $244,240,540,476$ \\
\hline & MT II (Mar II-Jui I) & $193,906,906,965$ & - & & $193,986,986,965$ \\
\hline & MT III (JuI II - Nov I) & - & $29,841,110,631$ & & $78,238,939,495$ \\
\hline & Total & $437,493,629,642$ & $30,575,400,430$ & $48,397,828,854$ & $516,466,866,996$ \\
\hline \multirow{4}{*}{$\begin{array}{l}\text { Alternatif III } \\
\text { (Awal Tanam } \\
\text { Desember l) }\end{array}$} & MTI(DesI-Mar II) & $254,006,640,735$ & $734,297,799$ & \multirow{3}{*}{$48,397,828,864$} & $244,760,938,534$ \\
\hline & MT II (Apr I-Juili) & $143,887,389,196$ & - & & $143,887,389,196$ \\
\hline & MT III (Aug I - Now II) & . & $33,990,050,613$ & & $82,387,879,477$ \\
\hline & Total & $397,914,029,932$ & $34,724,348,412$ & $48,397,828,854$ & $481,035,207,208$ \\
\hline \multirow{4}{*}{$\begin{array}{l}\text { Alternatif } N \\
\text { (Awal Tanam } \\
\text { Desember li) }\end{array}$} & MTI(Des $\| \cdot$ - Apr I) & $255,506,376,000$ & . & \multirow{3}{*}{$48,397,828,854$} & $255,506,376,000$ \\
\hline & MT $\|($ Apr II-Aug I $)$ & $104,345,448,508$ & - & & $104,345,848,508$ \\
\hline & MT III (Aug II- Des I) & - & $33,314,313,230$ & & $81,712,122,094$ \\
\hline & Total & $359,852,224,508$ & $33,314,313,2230$ & $48,397,828,864$ & $441,564,366,602$ \\
\hline
\end{tabular}

Sumber: Data Diolah

Gambar 16

Hasil Luas dan Intensitas Tanam Optimasi Skenario III

\begin{tabular}{|c|c|c|c|c|c|}
\hline \multirow{2}{*}{ Alternatif } & \multirow{2}{*}{ Ura'ian } & \multicolumn{4}{|c|}{ Keuntungan Hasil Pertanian (Rp/Tahun) } \\
\hline & & Padi & Palawija & Tebu & Total \\
\hline \multirow{4}{*}{$\begin{array}{l}\text { Alternatifl } \\
\text { (Awal Tanam } \\
\text { Novemberl) }\end{array}$} & MTI(NovI-Peb II) & $168,745,070,764$ & - & \multirow{3}{*}{$57,722,096,768$} & $168,745,070,754$ \\
\hline & MT II (Mar 1-Jun II) & $240,031,788,000$ & - & & $240,031,788,000$ \\
\hline & MT III (Jull-Okt II) & - & $25,109,407,245$ & & $82831,504,014$ \\
\hline & Total & $408,77,858,764$ & $25,109,407,246$ & $57,722,096,768$ & $491,609,362,779$ \\
\hline \multirow{4}{*}{$\begin{array}{l}\text { Alternatif II } \\
\text { (Awal Tanam } \\
\text { November II) }\end{array}$} & MTI (Nov III-Mari) & $268,984,040,478$ & $12,658,599,766$ & \multirow{3}{*}{$11,516,750,300$} & $281,642,640,244$ \\
\hline & MT॥(Mar II-Mil) & $193,193,525,520$ & $61,295,459,686$ & & $254,488,965,206$ \\
\hline & MT III (Jul III- Nov I) & - & $52,237,236,500$ & & $63,753,505,800$ \\
\hline & Total & $462,177,565,998$ & $126,191,284,952$ & $11,516,750,300$ & $599,895,611,260$ \\
\hline \multirow{4}{*}{$\begin{array}{l}\text { Alternatifill } \\
\text { (Awal Tanam } \\
\text { Desember I) }\end{array}$} & MTI(DesI-Mar II) & $335,827,584,000$ & - & \multirow{3}{*}{$\cdot$} & $335,827,584,000$ \\
\hline & MT II (Apr I-Juili) & $128,108,914,636$ & $73,015,172,976$ & & $203,124,087,612$ \\
\hline & MT III (Aug I-Novil) & - & $61,481,509,092$ & & $61,481,509,092$ \\
\hline & Total & $463,936,498,636$ & $136,456,682,069$ & - & $600,433,180,705$ \\
\hline \multirow{4}{*}{$\begin{array}{l}\text { Altematif IV } \\
\text { (Awal Tanam } \\
\text { Desember II) }\end{array}$} & MTI (Des II-Apr I) & $335,827,584,000$ & - & \multirow{3}{*}{ - } & $335,827,584,000$ \\
\hline & MT $\|($ Apr $\|$ - Avg I $)$ & $76,975,542,739$ & $73,015,172,976$ & & $151,990,715,765$ \\
\hline & MT III (Aug II - Des I) & - & $55,183,403,283$ & & $55,183,403,283$ \\
\hline & Total & $412,803,126,789$ & $130,198,576,259$ & - & $543,001,703,048$ \\
\hline
\end{tabular}

Sumber: Data Diolah

Gambar 17

Perhitungan Benefit Skenario III 
optimal (Rudson, Soetopo and Limantara, 2014;:Silvia, 2017). Hasil ini pada sisi lain bertolak belakang dengan studi yang maksimalkan pola tanam padi-palawijatebu untuk mendapatkan optimasi optimal (Sayekti, 2010; Setyono and Mucharom, 2016;Risfiyanto, Anwar and Margini, 2017).

\begin{tabular}{|c|c|c|c|c|c|}
\hline \multirow{2}{*}{ Altenatif } & \multirow{2}{*}{ Uraian } & \multicolumn{4}{|c|}{ Keuntungan Hasil Pertanian (Ap-Ttahun) } \\
\hline & & Padi & Palawija & Tebu & Total \\
\hline \multirow{4}{*}{$\begin{array}{l}\text { Atemnatifl } \\
\text { (Awal Tanan } \\
\text { November I) }\end{array}$} & MTI(NovI-Peb II) & $168,746,070,754$ & - & \multirow{3}{*}{$57,722,096,768$} & $168,746,070,754$ \\
\hline & MT II(Nar - Jun II) & $200,031,788,000$ & - & & $200,031,788,000$ \\
\hline & MT III (Jull - O Q XeII) & - & $25,109,407,245$ & & $82,831,504,014$ \\
\hline & Total & $408,7 m, 858,764$ & $25,109,407,246$ & $57,722,096,768$ & $491,609,362, \pi 9$ \\
\hline \multirow{4}{*}{$\begin{array}{l}\text { Alternatifil } \\
\text { (Awal Tanam } \\
\text { November I) }\end{array}$} & MTI(Nov II-Mer I] & $268,984,042,478$ & $12,658,599,766$ & \multirow{3}{*}{$11.516,760,300$} & $281,642,600,244$ \\
\hline & MTI(Nar II-Juil) & $193,193,525,520$ & $61,295,459,606$ & & $24,488,965,206$ \\
\hline & MT III (Jull|l-Novi) & . & $52,237,225,500$ & & $63,753,965,800$ \\
\hline & Total & $452,177,565,998$ & $126,191,284,952$ & $11,516,760,300$ & $599,855,611,250$ \\
\hline \multirow{4}{*}{$\begin{array}{l}\text { Alternatif II } \\
\text { (Awal Taran } \\
\text { Desember I) }\end{array}$} & MTI(DesI-MarII) & $335,827,524,000$ & - & \multirow{3}{*}{. } & $335,827,584,000$ \\
\hline & MT 1 (Apri-Juill) & $128,108,914,636$ & $75,015,172,976$ & & $203,124,087,612$ \\
\hline & MT III (Lag)-Novili) & - & $61,481,509,092$ & & $61,481,509,092$ \\
\hline & Total & $463,996,998,696$ & $136,496,662,069$ & . & $600,433,180,705$ \\
\hline \multirow{4}{*}{$\begin{array}{l}\text { AltematifilV } \\
\text { (Awal Tanan } \\
\text { Desember II)] }\end{array}$} & MTI(Des $\|\cdot A p r\|)$ & $335,827,584,000$ & . & \multirow{3}{*}{ - } & $335,827,584,000$ \\
\hline & MTII (Apr II- Aug II) & $76,97,542,789$ & $73,015,172,976$ & & $151,930,715,765$ \\
\hline & MT III (Aug II- DesI) & - & $55,183,403,283$ & & $55,153,403,253$ \\
\hline & Total & $412803,126, \pi 20$ & $130,188,576,259$ & . & $583,001,703,048$ \\
\hline
\end{tabular}

Sumber: Data Diolah

Gambar 18

\section{Hasil Luas dan Intensitas Tanam Optimasi Skenario III}

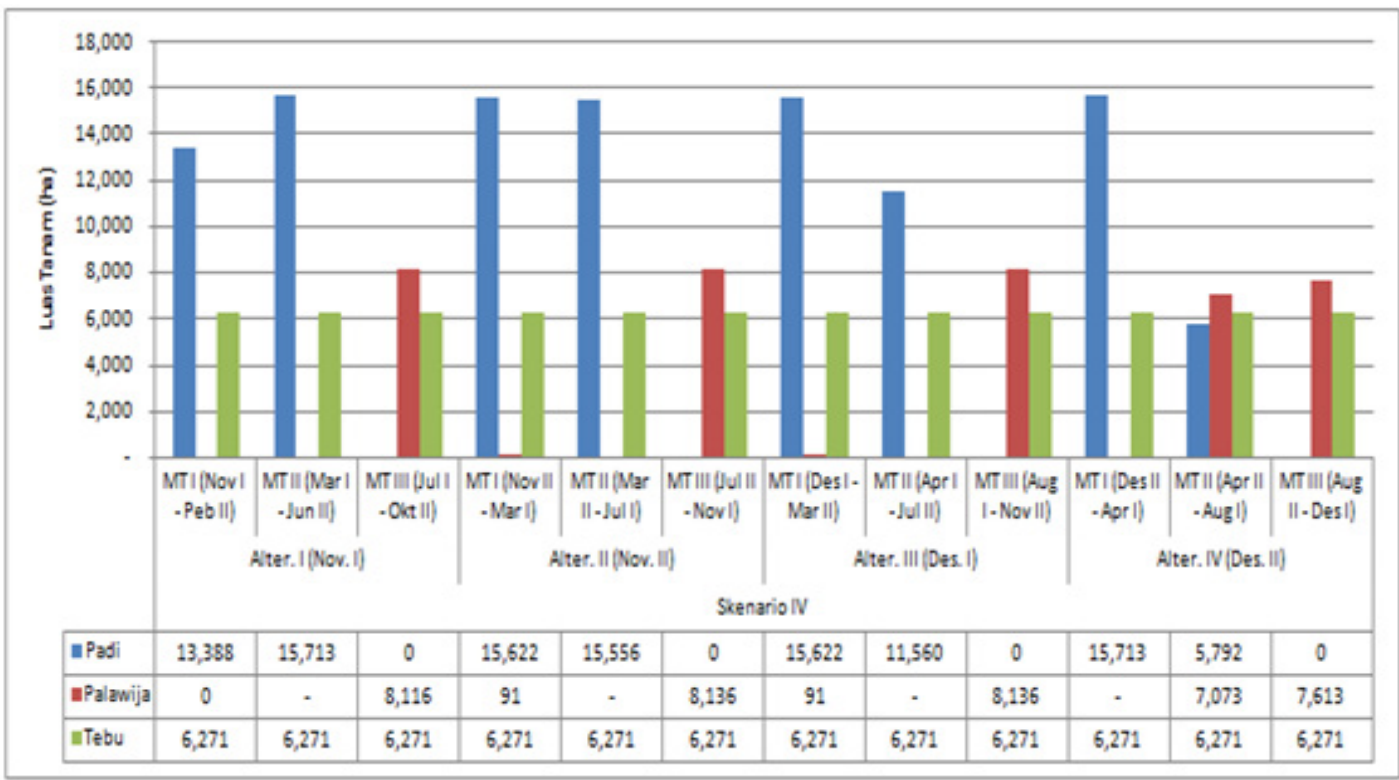

Sumber: Data Diolah

Gambar 19

Luas Tanam Optimasi Skenario IV 
Pada skenario IV ini luas dan alternatif 2 sebesar Rp. 596.366.157.184,intensitas tanam terbesar terjadi pada atau naik sebesar $17,34 \%$ dari keuntungan alternatif 2 sebesar $264,82 \%$ dengan awal yang diperoleh dari realisasi tanam tahun tanam November II, sedangkan untuk luas 2014/2015. Sedangkan keuntungan tanam padi terluas terjadi pada alternatif terkecil terjadi pada alternatif 4 sebesar Rp. 2 seluas 31.178 Ha. Dengan hasil tersebut 497.558.773.132,-. diperoleh keuntungan terbesar pada

\begin{tabular}{|c|c|c|c|c|c|}
\hline \multirow{2}{*}{ Atternatif } & \multirow{2}{*}{ Unaian } & \multicolumn{4}{|c|}{ Keuntungan Hasil Pertanian (Fo./Tahun) } \\
\hline & & Padi & Palwi⿵ī & Tebu & Total \\
\hline \multirow{4}{*}{$\begin{array}{l}\text { Alternatifi) } \\
\text { (Awal Tanam } \\
\text { Novemberi) }\end{array}$} & MTI(Nov1-Peb II) & $204,512,617,797$ & 0 & \multirow{3}{*}{$57,722,096,768$} & $204,512,617,797$ \\
\hline & $\operatorname{MTII}(\operatorname{Mar} \mid \cdot \operatorname{Jun} 11)$ & $240,031,708,000$ & $\cdot$ & & $242,031,788,000$ \\
\hline & MT III (Jull - Okt III) & - & $61,526,985,767$ & & $119,219,082,535$ \\
\hline & Total & $4,4,54,405,797$ & $61,526,905,707$ & $57,722,096,768$ & $563,793,488,332$ \\
\hline \multirow{4}{*}{$\begin{array}{l}\text { Aliernatif II } \\
\text { (Awal Tanam } \\
\text { November If) }\end{array}$} & MTI(Nov II-Mar I) & $238,641,672,000$ & $609,825,500$ & \multirow{3}{*}{$57,722,096,768$} & $239,331,497,500$ \\
\hline & MTII/(Marll-Jail) & $237,635,153,742$ & $\cdot$ & & $237,635,153,742$ \\
\hline & MT III (Jul II-Nov I] & - & $61,677,499,175$ & & $119,399,505,843$ \\
\hline & Total & $476,275,886,742$ & $62,367,234,675$ & $57,722,096,768$ & $596,366,157,184$ \\
\hline \multirow{4}{*}{$\begin{array}{l}\text { Alternatif III } \\
\text { (Awal Tanam } \\
\text { Desember I) }\end{array}$} & MTI(DesI-Mar II) & $238,641,672,000$ & $609,825,500$ & \multirow{3}{*}{$57,72,096,768$} & $239,331,497,500$ \\
\hline & MTII! & $176,597,167,532$ & - & & $176,597,157,532$ \\
\hline & MT III (Augg I - Nov III) & - & $60,632,427,333$ & & $118,354,524,101$ \\
\hline & Total & $415,238,839,532$ & $61,322,252,833$ & $57,722,096,768$ & $534,283,139,133$ \\
\hline \multirow{4}{*}{$\begin{array}{l}\text { Alternatif IV } \\
\text { (Awal Tanam } \\
\text { Desember II) }\end{array}$} & MTI(Des $\|$-Apri) & $240,031,788,000$ & (0) & \multirow{3}{*}{$57,722,096,768$} & $24,031,728,000$ \\
\hline & $\operatorname{MT} \|$ (Apr II-AuB I ) & $88,476,660,718$ & $53,616,876,500$ & & $142,093,537,218$ \\
\hline & MT $\| 1$ (Aug $\|$ - Des I) & - & $57,711,351,147$ & & $115,433,447,915$ \\
\hline & Total & $328,508,48,718$ & $111,328,227,647$ & $57,722,096,768$ & $497,558,773,132$ \\
\hline
\end{tabular}

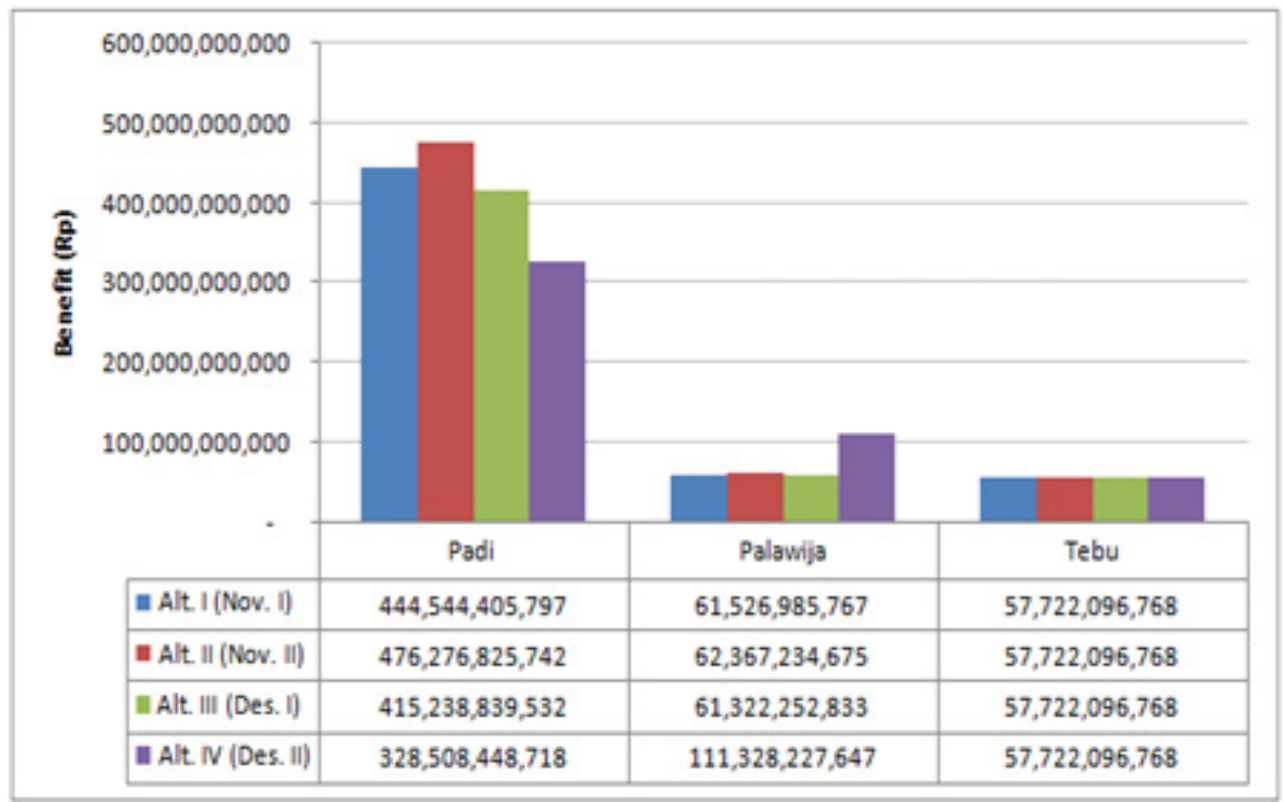

Sumber: Data Diolah

Gambar 20

Luas Tanam Optimasi Skenario IV 
SIMPULAN

Skenario III berdasarkan hasil analisis mampu memberikan keuntungan optimal paling tinggi bagi usahatani di daerah irigasi Delta Brantas. Guna mencapai keuntungan optimal tidak dilakukan penanaman tebu pada daerah irigasi Delta Brantas, tetapi memaksimalkan tanaman padi dan palawija. Keuntungan optimal yang diperoleh sebesar Rp.600.433.180.705,- dengan menggunakan alternatif 3 , di mana awal tanam dilakukan pada Desember I. Pola tanam yang diterapkan padi - padi/palawija - palawija, dengan luas tanam MT I: padi 21.984 ha, MT II: padi 8.386 ha, palawija (jagung/kedelai) 9.896 ha, MT III: palawija (jagung/kedelai) 8.110 ha.Penetapan RTTG di daerah irigasi Delta Brantas disarankan menyesuaikan dengan kondisi antara kebutuhan air dan ketersediaan air yang ada di bendung Lengkong. Dalam upaya meningkatkan hasil pertanian di Daerah Irigasi Delta Brantas, dapat dilakukan dengan membuat tampungan air (embung, long storage) di daerah hulu dari bendung Lengkong. Hal ini dilakukan agar saat musim kemarau dapat dimanfaatkan untuk menambah debit air di Daerah Irigasi Delta Brantas. Mengingat ketersediaan air di bendung Lengkong yang sangat potensial saat musim penghujan. Model matematis yang digunakan pada studi ini adalah dengan memaksimalkan faktor keuntungan (benefit). Sehingga untuk studi selanjutnya bisa dilakukan dengan memaksimalkan faktor lain seperti luas tanam, intensitas tanam dan lain-lain bahkan dilanjutkan dengan mengkaji pembuatan tampuan air untuk suplisi.

\section{UCAPAN TERIMA KASIH}

Penulis menyampaikan banyak terima kasih kepada Prof. Ir. Muhammad Syahril Badri Kusuma, Ph.D dan Dr. Ir. Suardi Natasaputra, M.Eng yang telah meluangkan waktu untuk memberikan saran dan masukan kepada penulis. Ucapan terima kasih juga disampaikan kepada Pemerintah Kabupaten Sidoarjo, BMKG Juanda dan UPTD Lengkong yang telah membantu kelancaran penelitian ini.

\section{DAFTAR PUSTAKA}

Bestari, A. S. (2017) Optimasi Pemanfaatan Air Sungai Keser Untuk Daerah Irigasi Ngasinan Menggunakan Program Linier. Institut Teknologi Sepuluh Nopember. Available at: http://repository.its.ac.id/44144/.

Frahmana, B. (2018) 'Optimasi Penggunaan Lahan Pertanian dengan Program Linier Studi Kasus : Jaringan Irigasi Saluran Sekunder Majalaya Bendung Walahar di Kabupaten Karawang', Jurnal Ilmiah Desain \& Konstruksi, 17(2), pp. 142-150.

Hafidh, M. (2009) Pengaruh Tenaga Kerja, Modal, dan Luas Lahan Terhdadap Produksi Usaha Tani Padi Sawah (Studi Kasus di Kecamatan Rowosari Kabupaten Kendal), Universitas Negeri Semarang. Universitas Negeri Semarang.

Hermanto, K., Utami, S. F. and Suarantalla, R. (2020) 'Optimasi Alokasi Air Irigasi Menggunakan Program Linier (Studi Kasus Bendungan Batu Bulan Kecamatan Moyo Hulu)', Barekeng: Jurnal Ilmu Matematika dan Terapan, 14(3), pp. 447-460.

Hidayat, Y. M., Harlan, D. and Winskayati (2014) 'Analisis Penggunaan Air Irigasi Dengan Teknik Analytical Hierarchy Process Di Wanir Kabupaten Bandung', Jurnal Sumber Daya Air, 10(1), pp. 1-12. 
Idfi, G. (2010) Studi Keseimbangan Air Pada Daerah Irigasi Delta Brantas (Saluran Mangetan Kanal) Untuk Kebutuhan Irigasi dan Industri. Institut Teknologi Sepuluh Nopember.

Jayadi, R. (1993) Pemakaian Model Program Dinamik Deterministik Secara Berurutan untuk Optimasi Sistem Waduk Seri. Yogyakarta.

Kanti Dwi Cahyani, W., Marimin, M. and Sukardi, S. (2017) 'Model Produktivitas Bagi Hasil Agroindustri Gula Tebu Dalam Kemitraan Antara Petani dan Perusahaan: Studi Kasus Di PG Kremboong, Sidoarjo', Jurnal Teknologi Industri Pertanian, 27(2),pp. 114-124.doi: 10.24961/j. tek.ind.pert.2017.27.2.114.

Ningsih, I. M., Dwiastuti, R. and Suhartini, S. (2015) 'Determinan Efisiensi Teknis Usaha Tani Kedelai', Jurnal Manajemen dan Agribisnis, 12(3), pp. 216-225. doi: 10.17358/ jma.12.3.216.

Noerhayati, E., Suprapto, B. and Syahid, A. A. (2017) 'Peningkatan Keuntungan Melalui Optimasi Sistem Pemberian Air Daerah Irigasi Molek Dengan Program Linier', Jurnal Teknika, 9(1), pp. 29-40. doi: 10.30736/teknika. v9i1.6.

Risfiyanto, L., Anwar, N. and Margini, N. F. (2017) 'Studi Optimasi Pola Tanam Pada Daerah Irigasi Baru Banyuwangi Dengan Menggunakan Program Linier', Jurnal Teknik Hidroteknik, 2(1), pp. 13-19. doi: 10.12962/ jh.v2i1.4397.
Rudson, R., Soetopo, W. and Limantara, L. M. (2014) 'Studi Optimasi Pola Tanam Daerah Irigasi Kosinggolan Di Kabupaten Bolaang Mongondow', Jurnal Teknik Pengairan, 5(1), pp. 130-140. Available at: https:// jurnalpengairan.ub.ac.id/index. php/jtp/article/view/212.

Saeri, M. (2018) Usahatani dan Analisisnya: Mempelajari Faktor Dalam Usahatani Beserta Analisisnya. Edited by $\mathrm{H}$. Subagyo. Malang: Universitas Wisnuwardhana Malang Press (Unidha Press).

Sayekti, R. W. (2010) 'Model Optimasi Alternatif Pola Tanam Untuk Mendapatkan Luas Tanam dan Keuntungan Yang Optimum (Studi Kasus di Dam Jatimlerek, Kabupaten Jombang)', Jurnal Teknik Pengairan, 1(2).

Setiawan, A. H. and Anwar, N. (2017) 'Optimasi Pola Tanam Menggunakan Program Linier (Waduk Batu Tegi, DAS Way Sekampung, Lampung)', Jurnal Teknik ITS, 6(1), pp. 1-6.

Setyono, E. and Mucharom, S. (2016) ‘Studi Optimasi Pola Tanam Daerah Irigasi Gong Gang Kecamatan Parang Kabupaten Magetan', Jurnal Media Teknik Sipil, 14(1), pp. 51-59. doi: 10.22219/jmts. v14i1.3289.

Silvia, E. (2017) Studi Optimasi Pemberian Air Irigasi Pada Saluran Induk Peterongan Daerah Irigasi Mrican Kanan. Institut Teknologi Sepuluh Nopember. 
Suharyanto (2005) 'Pengoperasian Waduk Tumiwa, K. and Sondakh, N. (2018)

Dalam Rangka Penanganan Bahaya Kekeringan Dan Banjir', Media Komunikasi Teknik Sipil, 13(1), pp. 60-70.

Suhesti, E. (2018) 'Analisis Efisiensi Dan Keuntungan Usaha Tani Tebu Metode Konvensional Dan Single Bud Planting (Studi Kasus Di Kecamatan Panji Kabupaten Situbondo)', CERMIN: Jurnal Penelitian, 2(2), pp. 175-190. doi: 10.36841/cermin_unars.v2i2.238.

Sukri, A. S. and Balany, F. (2017) 'Studi Optimalisasi Operasi Pembagian Air Pada Jaringan Irigasi Wawotobi Kecamatan Unaaha Kabupaten Konawe ( Studi Kasus : Jaringan Irigasi BW1 - B UN.5 TG)', Civil Engineering, 3(November), pp. 27-34.
'Maksimisasi Keuntungan Usaha Tani Pala Melalui Pengelolaan Sistem Agrobisnis di Kabupaten Minahasa Utara', Jurnal Bisnis dan Kewirausahaan, 14(2), pp. 80-91. doi: 10.31940/jbk.v14i2.1041. 
Lampiran 1. Tabel Perhitungan Kebutuhan Air Irigasi Untuk Pola Tanam Eksisting

\begin{tabular}{|c|c|c|c|c|c|c|c|c|c|c|c|c|c|c|c|c|c|c|c|c|c|c|c|c|c|c|c|}
\hline & & & Tor: & IE2X & DESEI & $152 \mathrm{R}$ & JAve & & $\mathrm{has}$ & tald & II. & & & NII & I & II & & N & & 피 & $d(t)$ & 515 & SLPII & IIE2R & OKI & 23K & \\
\hline No & URLIX & SATUN & 1 & II & I & II & I & II & 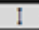 & II & 1 & II & 1 & II & I & II & & II & 1 & II & $\overline{1}$ & II & $\frac{1}{1}$ & II & $\bar{I}$ & $\overline{I I}$ & KII. \\
\hline & & & $B$ & 8 & $B$ & B & 15 & 16 & 14 & 14 & 15 & 16 & 15 & 15 & 15 & 16 & B & $B$ & $B$ & $\bar{r}$ & 8 & 16 & 15 & 15 & 13 & 16 & \\
\hline A & एक्यू & Fin & 4,5 & 45 & काना & काता & का & काना & का & 45ा & 4.5 & 4,4 & 456 & 4568 & 4586 & 456 & 456 & 1568 & & & & & & & & & \\
\hline & Ne foldncirea & my & 12.26 & 1000 & 5.15 & 4.4 & 287 & 237 & 218 & $(000)$ & 640 & 80 & 251 & 380 & 56 & 66 & 67 & 30 & & & & & & & & & \\
\hline & Sit folingureat & lath & 1.8 & 1.26 & 0.0 & 0.51. & 033 & 027 & 025 & 0 & 074 & 09 & 02 & 045 & 066 & 27 & 07 & 0.6 & & & & & & & & & \\
\hline & Datrine?kgrest & teth & 218 & 194 & 0.9 & 0.9 & 0.51 & 042 & 039 & . & 114 & 16 & 045 & 0.5 & 1010 & 118 & 12 & 0.64 & & & & & & & & & \\
\hline & Total Ketatuta Ga I & Ir'd & 99 & 8.80 & 420 & 3.00 & 234 & 193 & 177 & $\cdot$ & 532 & 667 & 29 & 32 & 47 & 5 & 50 & 301 & & & & & & & & & \\
\hline & & Bn & & 80 & [67. & 350 & 300 & 350 & 300 & 360 & 360 & 35.5 & 358 & 3318 & 3518 & 3518 & 3512 & 312 & 312 & & & & & & & & \\
\hline & Nit falliçirea & mit & & 1090 & 108 & 42 & 140 & 23) & 200 & 39 & -160 & 80 & 836 & 3.8 & 4.16 & 68 & 7007 & 69 & 3.6 & & & & & & & & \\
\hline & Ae folnotres & reth & & 1.26 & 1.26 & 0.51. & 016 & 027 & 030 & 046 & 0 & $\mathrm{OSO}$ & 097 & 045 & 048 & $07 \pi$ & 008 & 0.7 & 0.6 & & & & & & & & \\
\hline & Danina?quirest & leth & & 194 & 19 & 0.9 & 025 & 042 & 046 & 070 &. & 16 & 14 & 0.5 & 024 & 118 & 12 & 12 & 0.65 & & & & & & & & \\
\hline & Iotl Ketotubn GA II & Ird & & 72 & 7.10 & 28 & Q92 & 155 & 170 & 257 & . & 50 & 523 & 20 & 20 & 415 & 48 & 48 & 250 & & & & & & & & \\
\hline & & & & & & 608 & 686 & 666 & 686 & 685 & 606 & 660 & 6,8 & 6.8 & 68 & 676 & 678 & 68 & 66 & 68 & & & & & & & \\
\hline & Nit faldocirea & $\mathrm{Bz}$ & & & 108 & 10.4 & 140 & 0,0 & 200 & 435 & 18 & 000 & 836 & $9 \%$ & 416 & 5.12 & 700 & 7.17 & 131 & 3.67 & & & & & & & \\
\hline & Nit foldocirasea & $m h$ & & & 126 & 1.7 & 016 & 010 & 030 & 050 & 021 & 000 & 097 & 11.2 & 048 & 0.5 & 0.8 & 0.8 & 0.5 & 0.6 & & & & & & & \\
\hline & Dunime?cyreat & teth & & & 194 & 18. & 025 & 016 & 046 & 077 & 0.32 & 000 & 14 & 173 & 024 & $0 \%$ & 12. & 128 & 131. & 0.5 & & & & & & & \\
\hline & Iotd Ketatuta GA III & Ittha & & & 204 & $20 \pi$ & 167 & 107 & 309 & 318 & 217 & $\mathrm{OQSO}$ & 1003 & 110 & 500 & 615 & 89 & 8.60 & 884 & 1.0 & & & & & & & \\
\hline B & PALATIAA & $\mathrm{B}_{2}$ & & & & & & & & & & & & & & & & & & 759 & 254 & 394 & 734 & 394 & 734 & & \\
\hline & Mit folincives & $m i$ & & & & & & & & & & & & & & & & & & 188 & 316 & 40 & 575 & 516 & 400 & & \\
\hline & 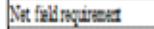 & reth & & & & & & & & & & & & & & & & & & 02 & 037 & 0.8 & 067 & 0,0 & 046 & & \\
\hline & Duxime?cquiest & tethe & & & & & & & & & & & & & & & & & & 0.35 & 0.86 & 082 & 102 & 092 & 071 & & \\
\hline & Total Ketantum Gal I & Ire & & & & & & & & & & & & & & & & & & 28 & 427 & 624 & 778 & 698 & 541 & & \\
\hline & & B2 & & & 25 & $2 \pi$ & $2 \pi$ & 28 & 27 & $2 \pi$ & & & 330 & 330 & 330 & 32 & 30 & 33 & & & $43 \%$ & 45:2 & $43 \%$ & 5\%: & 45:2 & 492 & \\
\hline & 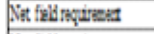 & min & & & 100 & 0.9 & $(100)$ & $(140)$ & $(10)$ & $(0 \%)$ & & & (145) & Q4 & 17 & 280 & & 2.2 & & & 236 & 316 & 530 & 5.7 & 526 & 40 & \\
\hline & 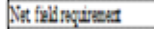 & teth & & & 0.12 & 0.10 & 0 & 0 & 0 & 0 & & & 0 & OCE & 021 & 033 & 0.54 & 0.2 & & & 027 & 037 & 0.64 & 0.0 & 0.8 & 046 & \\
\hline & Duxime? qqirest & reth & & & 0.18 & 0.16 & . & . & . & . & & & . & 008 & 0.3 & $05 \%$ & & 0.4 & & & 0.4 & 0.56 & 0.98 & 10 & 0.94 & 071 & \\
\hline & Totd Ketatube GA II & ard & & & 0.8 & 0.4 & . & . & . & . & & &. & QQD & 0120 & $011^{7}$ & 017 & 0.14 & & & 100 & 258 & 4.50 & 4.0 & 430 & 327 & \\
\hline & & $\mathrm{B}$ & 430 & & & & & & & & & & & & & & & & & & & 4230 & $4230 \mid$ & 423 & 430 & 430 & \\
\hline & Net filsmįues & $m i$ & 312 & & & & & & & & & & & & & & & & & & & 230 & 376 & 530 & 586 & 526 & \\
\hline & Nit foldocirea & letha & 0.38 & & & & & & & & & & & & & & & & & & & 021 & 044 & 0.4 & 0.88 & Q6! & \\
\hline & Durime?cgreat & Leth & 0.58 & & & & & & & & & & & & & & & & & & & 04 & 067 & 0.98 & 104 & 0,94 & \\
\hline & Iotal Ketatubar GA III & Ere & 23 & & & & & & & & & & & & & & & & & & & $1 \pi$ & 283 & 414 & 42 & 396 & \\
\hline c & IJg & Bn & 6,75 & 67. & 67) & (5) & $6,7 ?$ & 6.7:5: & $6,7 ! 3$ & 6773 & 6,75 & 6.75 & 6,75 & 6,25 & 6,75 & 6.72 & 6,2 & 6.78 & 5.52 & 558 & 532 & $55 \mathrm{X}$ & 552 & $55 \mathrm{~S}$ & 558 & 55 & \\
\hline & Net folingquea & zyt & 25 & 10 & $2 Q 8$ & 133 & .131 & .149 & .128 & 08 & .148 & 013 & 033 & 17 & 200 & 280 & 3.4 & 350 & 40 & 40 & 48 & 48 & 449 & 449 & 343 & 343 & \\
\hline & Mit foblocires & Leth & 028 & 013 & 024 & 015 & 0 & 0 & 0 & 000 & 0 & $O 00$ & 0.4 & 0.20 & 023 & 0.4 & 03 & 0.4 & 0.6 & 0.5 & 057 & 057 & 052 & 052 & 040 & 0.40 & \\
\hline & Dawime?qquest & teth & 0.4 & 019 & 037 & 024 & 000 & 000 & 000 & 008 & 000 & 002 & 0.06 & 031 & 036 & 0.53 & 0,8 & 00 & 0.3 & 0.3 & 088 & $08 \mathrm{~B}$ & 080 & 080 & 061 & 0.61 & \\
\hline & Totd Ketatitan & $=9 \mathrm{~d}$ & 280 & 12.2 & 2 s & 10 & 000 & 000 & 000 & 0.58 & 000 & 016 & 0.2 & 2.6 & 2.0 & 355 & 408 & 419 & 403 & 403 & 487 & 487 & HA & 42 & 338 & 338 & \\
\hline$D$ & TOTAL & ardi & 15.30 & 172 & 25.80 & 2024 & 493 & 154 & 636 & 833 & 249 & 1118 & 17.8 & 19.10 & 148 & 195 & 227 & 202 & 15.17 & 1106 & 1107 & 15.8 & 10.2 & 2024 & 178 & 10.0 & \\
\hline
\end{tabular}


Lampiran 2. Analisa Usahatani Padi, Kedelai dan Jagung per Hektar

\begin{tabular}{|c|c|c|c|c|}
\hline No & Uraian & Volume & $\begin{array}{c}\text { Harga } \\
\text { Satuan (Rp) }\end{array}$ & $\begin{array}{c}\text { Jumlah } \\
\text { (Rp) }\end{array}$ \\
\hline \multicolumn{5}{|c|}{ Padi } \\
\hline $\mathrm{A}$ & Biaya Produksi & & & \\
\hline 1 & Benih & $90 \mathrm{~kg}$ & 9.000 & 810.000 \\
\hline \multirow[t]{4}{*}{2} & Pupuk & & & \\
\hline & Urea & $300 \mathrm{~kg}$ & 1.800 & 540.000 \\
\hline & Phonska & $200 \mathrm{~kg}$ & 2.300 & 460.000 \\
\hline & Petroganik & $500 \mathrm{~kg}$ & 500 & 250.000 \\
\hline \multirow[t]{3}{*}{3} & Pengendalian OPT & & & \\
\hline & Rodentisida & $1 \mathrm{~kg}$ & 200.000 & 200.000 \\
\hline & Insektisida & $81 \mathrm{t}$ & 88.000 & 704.000 \\
\hline \multirow[t]{7}{*}{4} & Ongkos Tenaga Kerja & & & \\
\hline & Olah Lahan & $1 \mathrm{br}$ & 1.800 .000 & 1.800 .000 \\
\hline & Cabut Bibit dan Tanam & $1 \mathrm{br}$ & 2.180 .000 & 2.180 .000 \\
\hline & Penyiangan dan Penyulaman & $1 \mathrm{br}$ & 1.400 .000 & 1.400 .000 \\
\hline & Pemupukan & $8 \mathrm{HOK}$ & 60.000 & 480.000 \\
\hline & Pengendalian OPT & $6 \mathrm{HOK}$ & 60.000 & 360.000 \\
\hline & Panen dan Perontokan & $1 \mathrm{br}$ & 4.500 .000 & 4.500 .000 \\
\hline \multirow[t]{3}{*}{5} & Biaya Lain-lain & & & \\
\hline & Sewa Lahan & $1 \mathrm{ha}$ & 6.000 .000 & 6.000 .000 \\
\hline & Total A & & & 19.684 .000 \\
\hline \multirow[t]{2}{*}{$\mathrm{B}$} & Pendapatan & & & \\
\hline & Pemasukan (GKP) - kw/ha & $76 \mathrm{kw}$ & 460.000 & 34.960 .000 \\
\hline \multirow[t]{2}{*}{$\mathrm{CH}$} & Keuntungan Bersih (B-A) & & & 15.276 .000 \\
\hline & Kedela & & & \\
\hline $\mathrm{A}$ & Biaya Produksi & & & \\
\hline 1 & Benih & $8 \mathrm{~kg}$ & 12.000 & 96.000 \\
\hline & Pupuk & & & \\
\hline & PPC (Pupuk Pelengkap Cair) & $11 \mathrm{t}$ & 23.000 & 23.000 \\
\hline \multirow[t]{2}{*}{3} & Pengendalian OPT & & & \\
\hline & Insektisida & $1,5 \mathrm{~kg}$ & 140.000 & 210.000 \\
\hline \multirow[t]{6}{*}{4} & Ongkos Tenaga Kerja & & & \\
\hline & Babat Jerami \& Pembuatan Saluran Air & $1 \mathrm{br}$ & 350.000 & 350.000 \\
\hline & $\begin{array}{l}\text { Tugal, Icir Benih, Penyiangan, Pemupukan } \\
\text { (Pria) }\end{array}$ & $1 \mathrm{br}$ & 180.000 & 180.000 \\
\hline & Pengendalian OPT & $1 \mathrm{br}$ & 150.000 & 150.000 \\
\hline & Panen, Penjemuran (Pria) & $2 \mathrm{HKP}$ & 80.000 & 160.000 \\
\hline & Perotokan & $4 \mathrm{kw}$ & 50.000 & 200.000 \\
\hline
\end{tabular}




\begin{tabular}{|c|c|c|c|c|}
\hline No & Uraian & Volume & $\begin{array}{c}\text { Harga } \\
\text { Satuan (Rp) } \\
\end{array}$ & $\begin{array}{c}\text { Jumlah } \\
\text { (Rp) }\end{array}$ \\
\hline \multirow[t]{4}{*}{5} & Biaya Lain-lain & & & \\
\hline & Sewa Lahan & 0,2 ha & 2.500 .000 & 500.000 \\
\hline & Konsumsi Tenaga Kerja & $1 \mathrm{br}$ & 200.000 & 200.000 \\
\hline & Total A & & & 1.969 .000 \\
\hline \multirow[t]{2}{*}{$\mathrm{B}$} & Pendapatan & & & \\
\hline & Pemasukan (kg/ha) & $1200 \mathrm{~kg}$ & 6.200 & 7.440 .000 \\
\hline \multirow[t]{2}{*}{$\mathrm{C}$} & Keuntungan Bersih (B-A) & & & 5.471 .000 \\
\hline & \multicolumn{4}{|c|}{ Jagung } \\
\hline $\mathrm{A}$ & Biaya Produksi & & & \\
\hline 1 & Benih & $25 \mathrm{~kg}$ & 30.000 & 750.000 \\
\hline \multirow[t]{4}{*}{2} & Pupuk & & & \\
\hline & Urea Tablet & $300 \mathrm{~kg}$ & 1.500 & 450.000 \\
\hline & TSP & $100 \mathrm{~kg}$ & 1.800 & 180.000 \\
\hline & $\mathrm{KCI}$ & $50 \mathrm{~kg}$ & 8.000 & 400.000 \\
\hline \multirow[t]{2}{*}{3} & Pengendalian OPT & & & \\
\hline & Insektisida & $2 \mathrm{~kg}$ & 140.000 & 280.000 \\
\hline \multirow[t]{9}{*}{4} & Ongkos Tenaga Kerja & & & \\
\hline & Pengolahan Tanah & $1 \mathrm{br}$ & 750.000 & 750.000 \\
\hline & Persemaian, Penyiangan & $1 \mathrm{br}$ & 750.000 & 750.000 \\
\hline & Tanam & $1 \mathrm{br}$ & 300.000 & 300.000 \\
\hline & Pemupukan & $20 \mathrm{HOK}$ & 30.000 & 600.000 \\
\hline & Pengendalian OPT & $4 \mathrm{HOK}$ & 30.000 & 120.000 \\
\hline & Panen & $10 \mathrm{HOK}$ & 30.000 & 300.000 \\
\hline & Perontokan & $10 \mathrm{HOK}$ & 30.000 & 300.000 \\
\hline & Pengeringan & $4 \mathrm{HOK}$ & 30.000 & 120.000 \\
\hline \multirow[t]{3}{*}{5} & Biaya Lain-lain & & & \\
\hline & Sewa Lahan & 0,5 ha & 2.500 .000 & 1.250 .000 \\
\hline & Total A & & & 6.550 .000 \\
\hline \multirow[t]{2}{*}{$\mathrm{B}$} & Pendapatan & & & \\
\hline & Pemasukan (kg/ha) & $5.800 \mathrm{~kg}$ & 2.800 & 16.240 .000 \\
\hline $\mathrm{C}$ & Keuntungan Bersih (B-A) & & & 9.690 .000 \\
\hline
\end{tabular}

Sumber : Data Diolah 